\title{
Beyond the mouse: non-rodent animal models for study of early mammalian development and biomedical research
}

\author{
ZOFIA E. MADEJA*,1, PIOTR PAWLAK ${ }^{1}$ and ANNA PILISZEK*,2 \\ ${ }^{1}$ Faculty of Veterinary Medicine and Animal Sciences, Poznan University of Life Sciences, Poznan, Poland and \\ ${ }^{2}$ Institute of Genetics and Animal Breeding, Polish Academy of Sciences, Jastrzebiec, Poland
}

\begin{abstract}
The preimplantation development of mammals generally follows the same plan. It starts with the formation of a totipotent zygote, and through consecutive cleavage divisions and differentiation events leads to blastocyst formation. However, the intervening events may differ between species. The regulation of these processes has been extensively studied in the mouse, which displays some unique features among eutherian mammals. Farm animals such as pigs, cattle, sheep and rabbits share several similarities with one another, and with the human developmental plan. These include the timing of epigenetic reprogramming, the moment of embryonic genome activation and the developmental time-frame. Recently, efficient techniques for genetic modification have been established for large domestic animals. Genome sequences and gene manipulation tools are now available for cattle, pigs, sheep and goats, and a larger number of genetically engineered livestock is now accessible for biomedical research. Yet, these animals still make up less than $0.5 \%$ of animals in research, mainly due to our inadequate knowledge of the processes responsible for pluripotency maintenance (to date no stable naïve embryonic stem cell lines have been established) and early development. In this review, we highlight our present knowledge of the key preimplantation events in the 3 non-rodent species which present the highest potential for biomedical research related to early embryonic development: cattle, which offer an excellent model to study human in vitro embryo development, pigs which emerge as models to study the long-term effects of genebased therapies and rabbits, which in many aspects of embryology resemble the human.
\end{abstract}

KEY WORDS: embryo, embryonic stem cell, cattle, pig, rabbit

\section{Introduction}

The fundamental plan of mammalian preimplantation development is universal for all mammals. It starts with a formation of a totipotent zygote and through many rounds of cellular divisions and differentiation leads to the formation of a blastocyst. During this phase, the first lineage specification occurs resulting in the segregation of the outer, unicellular layer of epithelialized cells named the trophectoderm (TE). This is accompanied by a formation of the inner cell mass (ICM) which thereafter segregates into the pluripotent epiblast (EPI - the nascent embryo proper) and the differentiated primitive endoderm ( $\mathrm{PrE}$ ) or hypoblast (HP). The TE cells will subsequently give rise to the embryonic part of the placenta after blastocyst implantation in the uterus. While the starting point (zygote) and the endpoint (blastocyst) are conserved among the species, the intervening events have diverged across mammals. The differentiation of the outer layer of cells is already underway by the morula stage, while the population of the early

Abbreviations used in this paper: ART, assisted reproductive technology; dpc, days post coitum; dpi, days post insemination; DMR, differentially methylated regions; EGA, embryonic genome activation; EPI, epiblast; EpiSC, epiblast-derived stem cell; ESC, embryonic stem cell; ERK, extracellular signal-regulated kinase; FF, follicular fluid; FGF, fibroblast growth factor; HP, hypoblast; hpi, hours post insemination; ICM, inner cell mass; iPSC, induced pluripotent stem cell; JAK, janus kinase; IVF, in vitro fertilisation; LIF, leukemia inhibitory factor; MAPK, mitogen-activated protein kinase; MEK, MAPKK, mitogen-activated protein kinase kinase; PA, parthenogenetic activation; PGC, primordial germ cell; PrE, primitive endoderm; SCNT, somatic cell nuclear transfer; STAT, signal transducer and activator of transcription; TE, trophectoderm; VHP, visceral hypoblast, XCI, $\mathrm{X}$ chromosome inactivation.

\footnotetext{
*Address correspondence to: Zofia E. Madeja. Department of Genetics and Animal Breeding, Faculty of Veterinary Medicine and Animal Sciences, Poznan University of Life Sciences, Wolynska 33, 60-637 Poznan, Poland. Tel: +48 61846 6111. Fax: +4861 8487148. E-mail: zmadeja@up.poznan.pl

- web: http://jay.up.poznan.pl/GENETYKA/index.php?lang=en - (D https://orcid.org/0000-0001-9649-2422 or Anna Piliszek. Department of Experimental Embryology, Institute of Genetics and Animal Breeding of the Polish Academy of Sciences, ul. Postepu 36A, Jastrzebiec, 05-552 Magdalenka, Poland. Tel: +48 22 7367036 . Fax: +48 22 756-14-17. E-mail: a.piliszek@ighz.pl - web: http://www.ighz.edu.pl/en - (iD https://orcid.org/0000-0003-1449-3523
} 


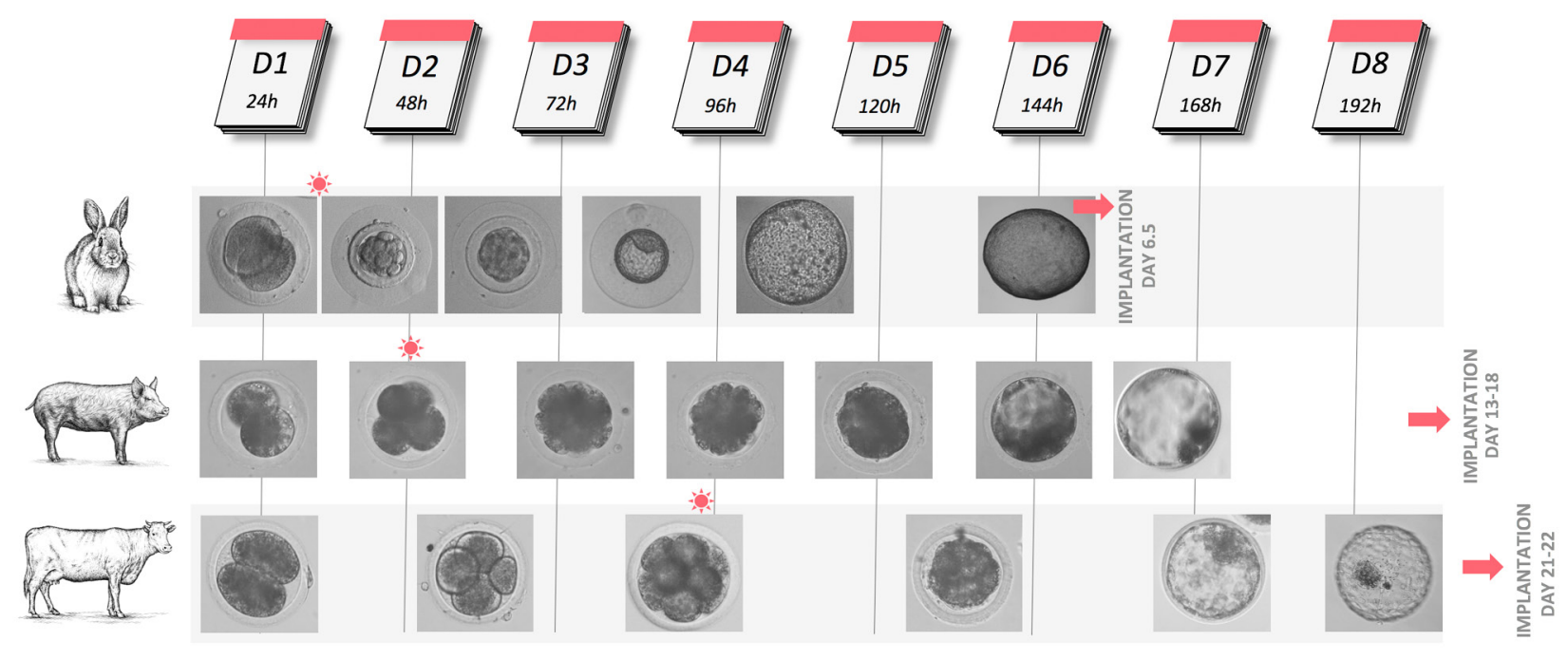

Fig. 1. Comparison of the morphology and timing of the preimplantation development of rabbit, pig and bovine embryos. $D$, days of embryonic development; h, hours post insemination; asterisk, Embryonic Genome Activation (EGA).

inner cells will retain its pluripotent state allowing the EPI formation. The genetic regulation of these processes has been extensively investigated in the mouse, yet the mechanisms involved are not always evolutionarily conserved. In comparison to other mammals such as ungulates, carnivores or primates, mouse preimplantation development is very short - the blastocyst is formed 3 days post coitum (dpc) and is quickly subjected to an invasive implantation at $4.5 \mathrm{dpc}$. This contrasts with blastocyst formation at 3-6 dpc in rabbit, 5-6 dpc in human, 6-7 days post insemination (dpi) in pig and horse, 7-8 dpi in sheep and 8-9 dpi in the cow (Fig. 1). In some species, the time gap between the blastocyst formation and implantation may be considerably extended in time: 6-11 days in pigs (Bazer and Johnson, 2014), 6-8 days in sheep (Bindon, 1971), 10-13 days in cattle (Peippo et al., 2011) and 28 days in horse (Stout et al., 2005). In most of the domestic mammals differentiation before implantation is significantly more advanced than in the mouse. This includes hypoblast migration, further differentiation of the trophoblast, and gastrulation of the EPI compartment. For a detailed review refer to our previous publication (Piliszek and Madeja, 2018).

The period from fertilisation to the blastocyst formation is the most vulnerable in mammalian development. For example, 50-70\% of human embryos fail to reach the blastocyst stage and implant (Burruel et al., 2014, Ellish et al., 1996, Meseguer et al., 2011, Vanneste et al., 2009), similarly to some animal models. In cattle, the majority of embryo losses occur in the second week of gestation during which the blastocysts hatch (8-9 dpi) and the initial 3 lineages (EPI, HP and TE) are segregated (Berg et al., 2010). The EPI and the HPlineages are particularly sensitive to developmental perturbations (van Leeuwen et al., 2014). Studies have revealed that early cleavage events reflect the developmental potential of the embryo (Chavez et al., 2012). Consequently, the processes of cell fate regulation, embryo morphokinetic development and the maintenance of genomic stability are critical elements of developmental competence acquisition. Therefore, in this review we will concentrate on similarities (and differences) in embryonic lineage commitment and pluripotency maintenance in mammalian embryos (non-rodent versus human). This is particularly important in the context of establishing animal models to study human preimplantation development, as many fundamental aspects of the early stages of human development are found to be conserved in non-rodent mammals.

\section{The ungulate model: cattle and pigs in biomedical research}

The development of new therapies and diagnostic methods in human medicine requires animal models, as in vitro systems are incapable of modelling a whole organism pathophysiology. Nonrodent species may complement the preclinical studies conducted on mice, as many new therapies fail in the clinical trials because they do not allow to predict the safety and effectiveness in human patients. The lack of consent and the ethical issues arising from using primates in biomedical research place other large animals as a necessary element of preclinical trials. Due to their lifespan, anatomy and physiology farm animals may be used to test the long-term effects of gene therapy, stem cell and induced pluripotent stem cell (iPSC) treatments. Livestock may also indicate the obstacles arising from the application of medical advances in outbred populations.

Pigs have proven to be an important model for cardiovascular diseases, colorectal cancer, osteosarcoma, diabetes, cystic fibrosis, Duchenne muscular dystrophy and Alzheimer's disease (reviewed in Perleberg, 2018). Pigs are also becoming a very attractive species to test stem cell therapies of a spinal cord injury (Kim, 2018). The advantage of using pigs arise from their relatively short time of pregnancy ( 115 days, in comparison to 283 in cattle), high fertility, and a possible direct translation of surgical techniques (such as endoscopy) which may be implemented in testing various medical diagnostic and therapeutic procedures. Similar organ size and the heart stroke volume places the domestic pig at the first place of the potential donors for xenotransplantation.

Due to the similarities in the reproductive cycles, cows become an important model to study human female fertility in the aspects of the ovarian function (Yapura et al., 2011), the effects of ageing on fertility (Malhi et al., 2005), and certain aspects of uterine infec- 
tion and immunity (Herath et al., 2006). The bovine model also facilitates studies on embryo-maternal communication and assisted reproduction techniques (reviewed in Bahr and Wolf, 2012). Other applications of cattle in biomedical research include studies of tuberculosis (and vaccine development) as Mycobacterium strains are similar in human and cattle (Waters et al., 2011). Cattle also plays a minor role as biomechanical models for orthopedic surgery (Bisson et al., 2008).

Genetic modifications of livestock became possible with the development of pronuclear DNA injections in the 1980s (Hammer, 1985), however, this method results in random transgene integration. The development of somatic cell nuclear transfer (SCNT), allowed for the generation of genetically engineered animals such as rabbits, sheep, pigs and cattle. In this method, somatic cells (typically foetal fibroblasts) are modified to introduce the intended genetic modification. Despite a steady improvement, SCNT still remains low in efficiency (Callesan, 2014). The more recent development of gene editing tools (such as TALENs and CRISPR/Cas9) has had the greatest impact on the development of genetic modifications in pigs and cattle.

An unquestionable advance of using cattle and pigs for the purpose of biomedical research also arise from numerous similarities that are shared at the preimplantation period of development with humans, such as the kinetics of cell division, the timing of the embryonic genome activation (EGA) or the moment of blastocyst formation. The majority of biomedical and agricultural applications rely on oocytes as the source of in vitro produced embryos, thus a detailed understanding of species-specific preimplantation development events is essential for the experimental success.

\section{Cattle - early embryonic development}

The early cell lineage specification in the mouse embryo has been broadly reviewed and described by numerous authors (Nichols et al., 2009, Rossant et al., 2003, Saiz and Plusa, 2013). Our understanding of these processes is quite complete on many levels - i.e., molecular, cellular and spatiotemporal. However, in species such as cattle (and other non-rodent mammals), the available information is still limited. Only in recent years, the developmental biologists took an interest in the farm animals and understood their importance for biomedical research and for unravelling the secrets of mammalian embryogenesis.

Mice display unique features, such as the cup-shaped EPI, the maintenance of polar trophoblast, early epiblast cavitation, precocious allantois formation and a complex set of specialised cells involved in invasive implantation that are not typical for eutherian mammals and other rodents (Chazaud and Yamanaka, 2016, Chazaud et al., 2003, Kaufman, 1995). Recently a progress has been made in establishing rabbits and pigs as model systems for human development (reviewed in Piliszek et al., 2016), yet cattle embryos, which are of high economic importance and represent over 250 distinct ruminant species, are still less described.

The moment of major EGA may be associated with the initiation of major differentiation events within the embryo. In rodents the major burst of EGA takes place at the 2-cell stage (Aoki et al., 1997, Seshagiri et al., 1992, Zernicka-Goetz, 1994), while in other mammalian species this process spans several cell cycles and occurs close to the first cell differentiation events, just before the morula formation (Table 1).
TABLE 1

\section{TIMING OF THE MAJOR DEVELOPMENTAL EVENTS IN THE SELECTED MAMMALIAN SPECIES}

\begin{tabular}{lcccc} 
Species & $\begin{array}{c}\text { major EGA } \\
\text { cell stage }\end{array}$ & $\begin{array}{c}\text { Embryonic } \\
\text { day of EG }\end{array}$ & $\begin{array}{c}\text { morula stage } \\
\text { embryonic days }\end{array}$ & $\begin{array}{c}\text { blastocyst stage } \\
\text { embryonic days }\end{array}$ \\
\hline Human (Homo sapiens) & $4-8$ & 3 & 3 & $5-6$ \\
Cattle (Bos taurus) & $8-16$ & $3-4$ & 5 & $8-9$ \\
Pig (Sus scrofa) & $4-5$ & $4-5$ & $4-5$ & $6-7$ \\
Sheep (Ovis aries) & 8 & 3 & $4-5$ & $7-8$ \\
$\begin{array}{l}\text { Rabbit (Oryctolagus } \\
\text { cuniculus) }\end{array}$ & 4 & 1.5 & 2 & $3-6$ \\
Mouse (Mus musculus) & 2 & 1.5 & 3 & $3-4$ \\
\hline
\end{tabular}

It has been generally accepted for the mouse model, that a shift from totipotent properties of a zygote to the first cellular differentiation events may start as early as the 2-cell stage. Single blastomere of a 2-cell stage mouse embryo, obtained after the destruction of its counterpart, is capable of full-term development and creating a morphologically normal adult animal (Tarkowski, 1959). Such full developmental potential is only attained when the separated 2-cell stage blastomere generates a sufficient number of the epiblast cells (reviewed in Chen et al., 2018). Although viewed with caution, some studies show that independently developing 2- and 4-cell stage mouse blastomeres demonstrate inequality in totipotency. These authors showed that experimentally separated blastomeres are in some cases able to develop into two individual organisms, although several groups reported low efficiency of such procedure, suggesting that blastomeres at this stage may not possess equal developmental potential (Casser et al., 2017, Katayama etal., 2010, Tsunoda and McLaren, 1983). Other authors showed that a single cell of an 8-blastomere mouse embryo may still be competent enough to contribute to the ICM and/or the TE of a chimeric embryo, but this cell alone cannot develop into a viable offspring (Tabansky et al., 2013). In case of farm animals, the ability of a single cell to retain a full developmental potential is maintained at least up to the 4-cell stage, and it was the first method used to clone cattle and sheep. It was demonstrated that some of the individual blastomeres from 8-cell sheep embryos can give rise to an entire conceptus and that the viability of embryos produced by cell separation depends rather on the degree of reduction in the cell number than on the stage of development at which the separation was performed (Willadsen, 1981). In sheep, the efficiency of live births from separated 4-cell embryos was 36\% (Johnson et al., 1995). In cattle, embryos split into blastomeres at the 4-cell stage also developed to term, giving rise to multiple monozygotic healthy calves (Willadsen, 1980). Bisected or biopsied early bovine embryos gave pregnancy rates similar to those obtained from intact control embryos. It is a very important observation, showing that the timing of cell lineage specification among the mammalian embryos of different species is crucial to understand species-specific mechanisms of pluripotency maintenance. This has a further impact on the application of various bio-techniques in animal breeding and in research. For example, the efficiency of cloning, defined as the proportion of transferred embryos that results in a viable offspring is approximately 2 to $3 \%$ for all species. However, in cattle, the average cloning efficiency is ranging from 5 to 20\% (Kim et al., 2012). Among the factors thought to contribute to the greater success in cattle cloning are the relatively 
late EGA and the optimization of reproductive technologies, such as in vitro embryo production and embryo transfer, brought about by the cattle industry. Additionally, the efficiency of nuclear transfer technology may be enhanced by better understanding the nature of reprogramming using cow as a model animal, since approximately half of all SCNTs worldwide is performed in this species (Akagi et al., 2013, Tian et al., 2003).

\section{Mechanisms of pluripotency maintenance in cattle}

The first stable ESC lines were derived from mouse preimplantation embryos in 1981 (Evans and Kaufman, 1981, Martin, 1981), the first primate lines were published in 1995 (Thomson et al., 1995), human in 1998 (Thomson, 1998) and rat ESC in 2008 (Buehr et al., 2008). The 27-year long gap between mouse and rat ESCs shows the complexity of the system. The classical ESC derivation method relies on the activity of leukaemia inhibitory factor (LIF) in mouse and fibroblast growth factor (FGF) in human culture systems. Rat ESCs were derived only with the help of chemical inhibitors, which specifically eliminate differentiation inducing signalling. The classical ESC system is sufficient only for certain mouse strains and the initial lines were derived from the 129 strain that is consistently amenable to ESC derivation and genetic manipulation. Despite continuous efforts, the establishment of true/stable ESCs from farm animals remains elusive. Over the years, there have been numerous, sometimes contradictory, reports of successful ESC establishment from economically important ungulates, such as cattle and pigs, but the general consensus is that no stable, well-characterized ESC line from these species presently exists (Ezashi et al., 2016). The existing ungulate ESC lines exhibit several deficiencies ranging from short live in culture, inability to contribute to chimaeras, to germline transmission failure. The basis of this phenomenon may arise from the genetic background of the species (or even strain in case of mice) and the differences in the preimplantation development. These include the time-frame of preimplantation development, gene expression patterns, the timing of EGA, morula formation, initiation of lineage specification and even the cell number at each developmental stage.

As it was already stated, all mammals share the same developmental plan, but the intervening events between the zygote formation, the emergence of the blastocyst and implantation exhibit species-specific differences. Bovine preimplantation development in one of the longest in mammals and takes about 3 weeks. The zygote is formed up to 24 hours post insemination (hpi) and the first cleavage may be observed between 22-48hpi. For comparison, human zygote undergoes the first cleavage division between 2430hpi (Niakan et al., 2012) and mouse up to 16hpi (Sozen et al., 2014). Bovine morulae appear at day 5.0 and blastocysts at day $8-9$, this is however only a mid-stage leading to the implantation at day 21-22. During this period the embryo further differentiates, finally obtaining the elongated morphology. The Rauber's layer (i.e. the polar TE overlying the ICM/EPI) disappears by day 11-12 and the EPI increases in size laterally $(90-120 \mu \mathrm{m})$ and in thickness. At day $12-13$ the visceral hypoblast (VHP) may be noted underneath the EPI which is enlarged to a maximal diameter of $120-160 \mu \mathrm{m}$. Cavities began to appear separating the EPI from the VHP. Unlike in mouse and human embryos, gastrulation in cattle (and other ungulates) begins prior to implantation and takes place around 16 dpi. Mural TE proliferation causes further embryo extension, which finally reaches up to $20 \mathrm{~cm}$ in length before the implantation (Degrelle et al., 2005, van Leeuwen et al., 2015). Due to the differences mentioned above, for a long time, it was believed that bovine/ ungulate blastocyst may not be similar to the known mouse or human model of cell differentiation, lineage-specific signalling pathways activity and/or ICM/TE marker gene expression. The increasing body of evidence, however, shows that bovine blastocyst with its pluripotency status falls closely to the human and primate model.

The differentiation of the TE lineage may be regarded as the hallmark event in mammalian preimplantation development. The process of TE formation initiates with the emergence of the outer layer of cells around the morula stage. In the mouse, the embryo comprises 8 cells at the beginning of compaction and human and bovine embryos begin this process at 16 cell stage (Sozen et al., 2014). A fully compact bovine or human morula comprises about 32 cells (Sozen et al., 2014, Van Soom et al., 1997). The molecular interactions underlying the ICM/TE specification in cattle and in other ungulates still remain to be fully unravelled. However, our and other authors results show that the distribution of lineage-specific transcription factors in bovine blastocysts at day 8-9 mostly resemble the known models, but the differences are noted at the earlier stages. In the blastomeres of 5-cell stage bovine embryos, CDX2 and OCT4 positive signals were detected predominantly in the cytoplasm (Madeja et al., 2013). CDX2 was evenly distributed within the cytoplasm and absent in the nuclei and OCT4 was localised at the apical surface of the blastomeres. Changes in the sub-cellular and sub-nuclear distribution of pluripotency-related factors during the subsequent stages of bovine preimplantation development were noted. From 8-16 cell stage both proteins displayed a nuclear localisation. From the morula stage, the specific lineage segregation became visible, as OCT4 became ICM specific (with only a small proportion of TE cells being OCT4 positive) and CDX2 located solely in the TE layer. This observation may be explained by the work of Berg and colleagues (Berg et al., 2011) who showed that OCT4 expression in bovine TE may be retained even until the PrE/EPI segregation, indicating that the TE cells may not become lineage committed at equivalent stages to the mouse, or that different signalling factors regulate the maintenance of TE in cattle. It was shown that at the early stages, CDX2 does not repress OCT4 expression, as bovine OCT4 gene locus does not contain the cis-acting regulatory region necessary for extinguishing its transcription in TE (Berg et al., 2011). Furthermore, the TE cells of an early bovine blastocyst ( $7 \mathrm{dpi}$ ) retain the ability to contribute to the ICM derivatives in chimaeras. In support of this data, a recent study by Simmet and colleagues (Simmet et al., 2018) reports that the deletion of the OCT4 gene (by the CRISPR-Cas9 system) in bovine embryos did not affect the CDX2 expression in the TE. Control blastocysts showed a typical salt-and-pepper distribution of NANOG and GATA6 positive cells in the ICM, a pattern similar to that previously described in the mouse (Chazaud et al., 2006, Plusa et al., 2008). In contrast, NANOG was absent in the ICM of KO bovine blastocysts, and no cells expressing exclusively NANOG were visible (Simmet et al., 2018). This mimics the findings in OCT4-deficient human blastocysts (Fogarty et al., 2017), but remains in contrast to OCT4-null mouse blastocysts (Nichols et al., 1998). Studies performed on in vitro produced bovine embryos showed that the morula stage NANOG may be detected in the cytoplasm of certain cells, but at 8 dpi becomes ICM specific (Kuijk et al., 2008, Madeja et al., 2013). 
The key regulators of lineage specification belong to the large group of transcription factors, which play a pivotal role in ESC pluripotency maintenance and its induction in the somatic cells (iPSCs) (reviewed in Chen et al., 2017). Signal transducing pathways that were shown to be involved in embryogenesis include mitogen-activated protein kinase (MAPK), phosphatidylinositol 3-kinase (PI3K)/Akt, Wingless (WNT)/ $\beta$-catenin, bone morphogenetic protein (BMP)-SMAD, transforming growth factor (TGF) $\beta$, and Janus-activated kinase (JAK)/signal transducer and activator of transcription (STAT) pathway to name just a few (reviewed in Zhao and Jin, 2017). MAPK family plays an important role in many cellular processes and at least three MAPK families have been described: extracellular signal-regulated kinase (ERK) crucial for proliferation, differentiation and development, C-Jun $\mathrm{N}$-terminal kinase/stress-activated protein kinase (JNK/SAPK) with a role in proliferation, differentiation and apoptosis, and p38 kinase, which, in addition to proliferation and differentiation also participates in apoptosis, stress response, inflammation and development (reviewed in Zhang et al., 2007). MAPK/ERK signalling is activated by growth factors (such as Fibroblast Growth Factor 4, FGF4) and cytokines, consequently inducing lineage commitment and hypoblast formation. Antagonistically, active WNT pathway plays a key role in pluripotency maintenance. It acts as a regulator of embryonic cell patterning, differentiation, cell adhesion, survival and apoptosis, through a variety of signalling systems generally divided into canonical and non-canonical (reviewed in Logan and Nusse, 2004).

In mouse embryos, MEK/ERK signalling via the FGF receptor was shown to be involved in TE formation (Lanner and Rossant, 2010, Lu et al., 2008). The inhibitor-mediated modulation of ERK signalling activity was shown to enhance the efficiency of rodent ESC derivation by supporting the retention of OCT4 positive cells during the initial outgrowth formation (Buehr, 2002). However, ERK pathway inhibition alone is insufficient to support undifferentiated ESC in culture, unless the cells are maintained at high densities or provided with LIF (Ying et al., 2008). The maintenance of pluripotency in mouse and human ESCs is also possible through activation of WNT signalling via selected inhibition of glycogen synthase kinase 3 (GSK3) (Sato et al., 2004). Ying and colleagues (Ying et al., 2008) showed that the addition of a selective GSK3 inhibitor (GSK3i-CHIR99021) restored viability and allowed efficient expansion of undifferentiated mouse ESCs in the absence of ERK signalling. Based on these findings, Buehr and colleagues (Buehr etal., 2008) equipped with two sets of chemically defined signalling pathway inhibitors were able to establish stable rat ESC lines. In the 3 i system, the inhibitory effect on FGF signalling was supported by MEK/ERK pathway inhibition and WNT activity maintenance via the GSK3i. The $2 \mathrm{i}$ system relied only on the GSK3i and MEK/ ERK pathway inhibition. Both systems were supplemented with LIF which is necessary to suppress differentiation, maintain viability and growth rate when FGF/MEK/ERK signalling is reduced. The $2 \mathrm{i}$ system utilised a more selective and potent MEK inhibitor than the $3 \mathrm{i}$, thus eliminating the need to block the FGF receptor. Eventually, the $2 \mathrm{i}$ conditions proved optimal to derive rat ESC since it produced equivalent numbers of male and female cell lines and chromosomal abnormalities were not observed.

Still, a very limited amount of data exists with relation to the signalling requirement for the derivation of stable ESC lines from bovine embryos. The results of other authors (and our studies) show that WNT is active in bovine preimplantation embryos and that it affects lineage and pluripotency specific gene expression (Madeja et al., 2015). In vitroculture of bovine embryos in the presence of the GSK3i (CHIR99021) throughout the whole period of in vitro preimplantation development resulted in the upregulation of OCT4, NANOG, $c-M Y C$ and REX1 transcript expression in the ICM and OCT4 expression in TE, accompanied by downregulation of CDX2 expression in the TE (Madeja et al., 2015). Our unpublished data also suggests that the $2 \mathrm{i}$ and $3 \mathrm{i}$ systems may exert an effect on pluripotency marker gene expression in bovine blastocysts, as in the case of both of these systems the number of OCT4 and NANOG positive cells significantly increases both within the ICM and the TE. Studies by Ozawa and colleagues (Ozawa et al., 2012) showed that the exposure of bovine embryos to the $2 \mathrm{i}$ system at the time of morula to blastocyst transition facilitated the formation of self-renewing pluripotent cell lines from blastocysts and continuously maintained high NANOG and SOX2 expression. The positive effect of the $3 i$ system on bovine ESC lines survival and maintenance after thawing was also confirmed (Pashaiasl et al., 2013). MEK inhibitor used in the $2 \mathrm{i}$ system (PD0325901) stimulated bovine blastocyst development and the ICM cell number (McLean et al., 2014). Also, the $3 \mathrm{i}$ system improved blastocyst morphology, however the best results were noted in the $2 \mathrm{i}$ medium where FGF4 and NANOG transcripts were upregulated and PDGFRo and SOX17 downregulated. Thus it may be speculated, that at least at the mRNA level the inhibition of MAPK signalling prevents a natural shift from the EPI to HP state.

Pluripotent cell lines may exist in two states - naïve ESCs (equivalent to cells from the early epiblasts) and primed EpiSCs (developmentally more advanced epiblast stem cells). The genome of the naïve ESCs possesses a minimum of repressive epigenetic marks (Niwa, 2007), whereas EpiSCs have their epigenetic machinery active (Tesar et al., 2007). The transition from the naïve to the primed state represents a pivotal event in the embryonic differentiation. Studies suggest that the pluripotent state of human ESCs corresponds to mouse EpiSCs. Mouse naïve ESCs efficiently contribute to chimaeras, maintain both $\mathrm{X}$ chromosomes active in female lines and rarely submit to primordial germ cell differentiation (Nichols and Smith, 2009). These cells may be cloned with high efficiency, grow as packed dome colonies, are stabilised by LIF/ STAT3 and destabilised by basic Fibroblast Growth Factor (bFGF) and TGF $\beta /$ Activin signalling. In contrast, primed mouse EpiSCs exhibit flattened morphology, intolerance to passaging as single cells and rely on bFGF and TGF $\beta /$ Activin signals. Human ESCs share several important features with primed mouse EpiSCs. These include flattened morphology, intolerance to passaging as single cells, dependence on TGF $\beta /$ Activin signalling (Xu et al., 2008), inactivation of $\mathrm{X}$-chromosome in most of the derived female cell lines (Silva et al., 2008) and higher susceptibility to differentiate into PGCs in the presence of BMP4. The results of our studies led us to speculate that the derived bovine ES-like cells may share features of both these stem cell types (Madeja et al., 2015). The primary ESC lines from bovine embryos expressed transcripts for several pluripotency marker genes (OCT4, NANOG, REX1, SOX2, $c-M Y C$ and $K L F 4$ ). It was shown that overexpression of KLF4 may revert mouse EpiSCs back to an ES-like state (Guo et al., 2009). EpiSCs virtually do not express KLF4 but bovine cell lines derived in the presence of LIF and the GSK3i culture conditions maintained $K L F 4$ transcripts over several passages. JAK/STAT signalling was 
active at the initial stages of bovine ESC derivation - LIF had beneficial effects at the initial passages, but alone was inefficient to support prolonged self-renewal in primary bovine ESC culture. Similarly to mouse ESCs, WNT activity supported by LIF had a positive effect on cell culture propagation, survival after passage, morphology and pluripotency-related marker gene expression. The derived bovine ES-like colonies shared features of mouse EpiSC and human ESC morphology and grew as flat, mono-layer colonies intolerant to passaging as single cells (Madeja et al., 2015).

However, the issue of signalling pathway interactions in cattle may be much more complex. It was shown recently that employing a culture system containing FGF2 and an inhibitor of the canonical WNT signalling pathway Rho kinase (ROCK, Y-27632), allows for derivation of potentially pluripotent bovine ESCs with stable morphology, transcriptome, karyotype and population-doubling (Bogliotti et al., 2018). These cells were also used as donors for nuclear transfer and produced blastocyst at standard rate. Yet these results must be taken with caution, as other authors show that WNT signalling regulates development of bovine embryos to the blastocyst stage (Denicol et al., 2013). It has been postulated that the roles of different WNTs are variable according to developmental stage and factors such as cell environment, presence and abundance of different receptors and effector molecules (van Amerongen and Nusse, 2009). It is very likely that regulation of embryonic development by WNTs involves numerous receptors and signalling molecules participating in fine regulation of canonical and non-canonical pathways to balance maintenance of pluripotency, self-renewal and cell-fate commitment.

\section{Pig - early embryonic development}

The biomedical and agricultural applications of pigs as models for human diseases, stem cell research, transgenesis and cloning in many cases rely on the use of a large number of embryos obtained in vitro. Unfortunately, the efficiency of in vitro protocols including fertilisation, embryo culture and freezing is still unsatisfactory. Pig oocyte maturation procedures are based on well-established protocols that provide high (up to 90\%) rate of oocytes reaching the metaphase II stage (Pawlak et al., 2011). The subsequent stages, in particular gamete co-incubation, are still not reproducible between the laboratories and the results differ significantly within the published data. The attention in the field is mainly focused on culture media composition, semen selection, cytoplasmic maturation of oocytes, gamete co-incubation time, sperm concentration and embryo culture systems. Due to a high frequency of polyspermy, the gamete co-incubation time is drastically reduced (3-6h) and carried out with variable sperm concentrations. This approach allows to maintain an acceptable cleavage rate between 30 and $60 \%$ (Gil et al., 2004). One of the most interesting aspects of porcine assisted reproductive technologies (ART) is oocyte in vitro maturation culture media composition, which requires supplementation with $10-20 \% \mathrm{v} / \mathrm{v}$ of the follicular fluid (FF), collected from ovaries upon oocyte aspiration. This procedure positively influences the process of cumulus-oocyte complex maturation, reduces the rate of polyspermy, improves pronuclei formation in zygotes and positively affects embryo development to the blastocyst stage, probably by enhancing the effectiveness of cytoplasmic maturation (Brevini et al., 2005). The addition of the FF to the in vitro maturation media, a procedure unique to this species, is intriguing, as the conditions prevailing in the ovarian follicles are to some extent transferred to the in vitro system. Therefore, FF compounds such as amino acids, fatty acids, hormones and growth factors may affect both the oocyte and the cumulus cells during the entire period of in vitro maturation, making the system suboptimal. The issue of data reproducibility arises due to the stimulatory or the inhibitory effect of FF on oocytes and embryos, depending on its quantitative and qualitative composition (Bagg et al., 2007 Grupen et al., 2010, Pawlak et al., 2018). Moreover, working with an in vivo collected FF, demonstrating the action of a single factor is more difficult than in cattle, where IVM medium is supplemented with defined components such as fatty acids or amino acids. It is therefore difficult to compare porcine IVM to other species, also because the duration of this stage in the pig is $44 \mathrm{~h}$, which is considerably longer than in other mammals. On the other hand, the timing of porcine EGA (4-5 cells) and of blastocyst formation closely resembles human embryos and makes the pig a useful model for preimplantation development and ART research. Similar to cattle and other ungulates the differences arise after formation of the blastocyst, which further differentiates, to finally reach a very long filamentous shape (up to $60 \mathrm{~cm}$ in length) (Anderson, 1978) before the implantation, which starts at 13-18 dpi.

\section{Parthenogenetic embryos as an alternative for porcine IVF}

Porcine embryos derived as a result of artificially induced parthenogenetic activation (PA) possess a great diagnostic potential and may be used as an alternative to embryos obtained in classical in vitro fertilization procedure. The first attempts to obtain embryos relying only on the uniparental genome date back to early 1940s and 1960s and the first studies were done on rabbit and mouse PAembryos (Chang, 1954, Graham, 1970, Kaufman and Gardner, 1974, Pincus and Shapiro, 1940, Tarkowski, 1971, Tarkowski et al., 1970). With time, apart from a heat shock or hypoosmotic conditions, the use of chemical compounds to activate the oocyte and block the extrusion of the second polar body has been introduced. Today, the most effective activation stimuli rely on an electric impulse, what results in about $50 \%$ of porcine embryos developing to the blastocyst stage (Grupen et al., 2002). Ionomycin is a commonly used chemical activator of porcine oocytes yielding up to $30-40 \%$ of diploid blastocyst under standard embryo culture conditions. In some species, the development of PA beyond the blastocyst stage is observed ( $9.5 \mathrm{dpc}$ in mice) however, due to the phenomenon of genomic imprinting it is impossible to obtain a parthenogenetic mammalian offspring. On the other hand altering, by genome editing, just a few imprinted genes (of over 100 known) may result in circumvention of this barrier and enable the production of a viable animal from two maternal genomes (Moore et al., 2015). Kono and colleagues proved that increasing the activity of the lgf2 gene and monoallelic expression of the H19 gene lead to the generation of live offspring from parthenogenetic mouse embryos (Kono et al., 2004). In pigs, as well as in mice, rabbits and cattle, the aberrant expression of imprinted genes in parthenogenetic embryos has its origins in the epigenetic modifications, i.e. methylation patterns of DMR (differentially methylated regions) leading to failure in placenta formation and implantation (Han et al., 2013, Park et al., 2009, Park et al., 2011, Wang et al., 
2017). Interestingly, maternally and paternally imprinted genes were shown to be expressed in uniparental porcine embryos with some distinct differences between haploid and diploid parthenotes (Tilghman, 1999). Mammals cannot develop only on the basis of a uniparental genome, but parthenogenetic-normal chimaeras are spontaneously found. In human, it is possible to detect this phenomenon only by chance, as it was in the case of a boy, whose parthenogenetic cells contributed to the hematopoietic cell line (Strain et al., 1995). The proposed mechanism suggests that spontaneously activated oocyte was fertilized and a male pronucleus fused with one of haploid sets of oocyte, whereas the second underwent diploidization. Alternatively, activated oocyte underwent one or more divisions followed by fertilization of one of the resulting haploid blastomeres. Earlier studies on mice led to the birth of live chimaeras generated by the injection of ICM cells obtained from PA embryos to normal blastocysts (Surani et al., 1977). The ongoing debate on parthenogenetic embryos attempts to create a classification based on their developmental abilities and pluripotency status, by drawing parallels to the SCNT embryos, the iPS cells and embryos derived from IVF or conceived in vivo. These issues, also of a philosophical nature, have been recently described by Schickl and colleagues (Schickl et al., 2017). In 2014, the European Court of Justice, while debating on the proposal allowing to patent procedures of human embryonic stem cell derivation from parthenogenetic embryos, has judged that the PA embryos do not constitute a human embryo because of their incapacity to develop into a human being. Therefore, the studies on the derivation of ESCs from human PA embryos are ongoing and, interestingly, often generate better results than the embryos originating from the IVF procedures.

\section{Parthenogenetic embryos and ESC derivation}

In vitro culture of human embryos for the sole purpose of ESCs derivation is ethically controversial. Hence the idea of using parthenogenetic embryos enables the basic research and possible biomedical application bypassing the ethical barriers. The pluripotent ESCs retain the ability to differentiate into all embryonic lineages, survive multiple passaging, express pluripotency markers, form chimaeras after injection to blastocysts and contribute to the primordial germ cell (PGC) lineage. Ideally, they should also enable subsequent multiple gene targeting for the use in xenotransplantation. ESCs should also increase the efficiency of cloning, probably due to the fact that they are in a less differentiated state than fibroblasts and thus are more prone to reprogramming. The first attempts to produce putative porcine ESCs from in vivo obtained embryos date back to the 1990s (Chen et al., 1999, Evans et al., 1990, Piedrahita et al., 1990). Although in vivo derived embryos exhibit superior quality, their derivation is laborious and costly. A notable problem often observed in porcine IVF and PA embryos is a non-obvious ICM or only a few cells contributing to the residual ICM. It was shown that under the same culture conditions, parthenogenetic ICMs generate more outgrowths and adhere better during the initial stages of ESC derivation than ICMs originating from the IVF embryos, probably due to the increased expression level of integrin-1 and vitronectin (Brevini et al., 2010). This phenomenon was earlier described in human and murine parthenotes, giving hope for high-efficiency cell line establishment (Kim et al., 2007, Mai et al., 2007). The protocols to obtain human parthenogenetic embryos are also very efficient and result in 24$60 \%$ blastocyst rate, with ESC derivation efficiency of $50 \%$ (Kim et al., 2007, Mai et al., 2007, Revazova et al., 2008, Revazova et al., 2007). The human parthenogenetic stem cells (hpaESCs) exhibit morphological properties similar to hESCs, express the same pluripotency markers, have comparable telomerase activity and form teratomas when injected into mice. No clinical trials have been reported so far of hpaESC application, however studies on mice and monkeys (Macaca fascicularis, Cyno-1 cells) clearly indicate their great therapeutical potential, as it was shown that these cell lines may differentiate into hepatocytes or dopamine neurons restoring motor function in hemiparkinsonian rats (Cibelli et al., 2002, Sanchez-Pernaute et al., 2008, Vrana et al., 2003). Porcine paESCs expressing green fluorescent protein (GFP) and differentiated into the neural lineage were used to cure a spinal cord injury in rats and an induced periodontitis in minipigs. Both models revealed the therapeutic potential of paESCs showing significant tissue recovery with no signs of teratoma formation (Yang et al., 2013a, Yang et al., 2013b).

In 2010 a new approach in porcine ESC derivation was proposed with regard to culture media (minimal essential medium (MEM) with $10 \%$ serum replacement, bFGF, LIF, Activin $A$ and human recombinant EGF) and culture conditions (5\% oxygen concentration) (Vassiliev et al., 2010). Day 7 in vitro blastocysts and day 6 in vivo obtained blastocysts with removed zona pellucida cultured on mouse embryonic fibroblasts (MEFs) produced homogenous outgrowths and sustained passaging after vitrification. These cell lines expressed OCT4, NANOG and SSEA-1, were able to differentiate into three germ layers and contribute to ICMs, leading to the birth of chimeric piglets (Vassiliev et al., 2010). Nevertheless, additional studies are needed to prove the germline transmission and chimaera generation from later passages, to state the pluripotent nature of these ESCs. The same group showed that ESC lines may be derived with the help of trichostatin A (which was shown to improve SCNT embryo development) from nuclear transfer porcine embryos at around $10 \%$ efficiency (Beebe et al., 2009, Kishigami et al., 2006, Vassiliev et al., 2011). These lines expressed OCT4 and NANOG (but not the trophectoderm specific markers such as the CDX2), maintained stability up to 15 passages and formed embryoid bodies, although no data on chimaera formation and other characteristics have been published (Vassiliev et al., 2011). MEFs are still considered to provide the best feeder layer for the culture of porcine ESCs, but a debate exists regarding the influence of LIF and FGF signalling. There are no conclusive results showing the presence of LIFR in porcine ICM and EPI. Nevertheless, studies show that LIF improves cell attachment, self-renewal and maintenance of ESC culture in the undifferentiated state, suggesting its action via the alternative pathway involving PI3K, AKT and PTEN (Brevini et al., 2012, Brevini et al., 2010, Brevini et al., 2008).

Compared to other species, pigs demonstrate differences in pluripotency and lineage-specific marker gene expression (Wolf et al., 2011). In the mouse embryo, NANOG and OCT4 are found at the morula stage, and later become restricted solely to ICM cells, with OCT4 being quickly downregulated in the TE (Palmieri et al.,1994). Earlier studies showed no expression of NANOG in porcine blastocyst and detected OCT4 both in the ICM and in the TE cells (Kuijk et al., 2008). However, our preliminary study (Pawlak unpublished) indicate the expression of NANOG in PA 
porcine blastocysts. Moreover, OCT4 transcripts were detected throughout the entire period of preimplantation development, therefore it is of great importance to carefully analyse the distribution of pluripotency-related markers in different species. The low expression of NANOG may be sufficient to take an action as a pluripotency-related transcription factor at a particular stage of embryonic development. Brevini and colleagues showed a constant expression of NANOG in porcine ESC lines, contrary to OCT4 which is downregulated after few passages, suggesting its key regulatory function at earlier (embryonic) stages in the ICM or the epiblast (Brevini et al., 2010). In support of these observations, Du Puy and colleagues detected high levels of NANOG transcripts in the ICM of the expanded porcine blastocyst, which was maintained also in the epiblast (du Puy et al., 2011). In contrast to the mouse, in porcine embryos $C D X 2$ begins to be expressed later in the development and its expression is restricted to the trophectoderm at day 9.5 of development (du Puy et al., 2011). Other pluripotency factors such as surface markers SSEA1, SSEA3, SSEA4 also exhibit species-specific expression patterns, therefore a global gene expression analysis of porcine ICM, TE and EPI is needed to characterize the real molecular picture of embryonic development and subsequently derived ESCs.

Since only cell lines from early passages have been positively verified in the chimera assay, a question has been raised, how long the ESCs would maintain the undifferentiated state in vitro.

In case of pluripotent stem cell derivation, many factors need to be considered, for example the source of embryos, embryo developmental stage, whether the isolated ICMs or the whole embryos are used, the frequency of passaging and the culture media used. Haraguchi and colleagues established self-renewing porcine ES-like colonies which underwent over 100 passages, under specific LIF dependent conditions using the inhibitors of MEK/ ERK (PD184352) and GSK $\beta$ (CHIR99021) signalling (Haraguchi et al., 2012). The embryoid body formation and the expression of the three germ layer specific factors (in the presence of LIF and the inhibitors of MEK and GSK $\beta$ ) was also shown in porcine iPSCs, suggesting the importance of MEK/ERK and WNT signalling in the establishment of the naïve-like state (Rodríguez et al., 2012). Recently, a few articles provided new insights into different porcine stem cell populations derived from the early embryos. A comparative study showed that porcine ESCs established from in vitro obtained embryos, parthenotes and nuclear transfer iPSCs (iPS-NT) (Kim et al., 2016) expressed OCT4, NANOG, SOX2, REX1, NROB2, KLF2 and factors involved in the signalling pathways activated in human primed ESCs such as FGFR1 and FGFR2. These authors also showed that iPS-NT cells have some unique characteristics - they proliferate faster, upregulate REX1 and FGFR2 and contain a less mature form of mitochondria, but, in contrast to other cell lines, exhibit multiple aberrant patterns of nuclear H3K27me3 foci suggesting their epigenetic instability. Earlier, Hall and Hyttel showed that FGF and JAK/ STAT signalling is critical for the maintenance and proliferation of porcine pluripotent cells in vitro. Porcine embryos express surface markers typical for both mouse (SSEA-1) and human ESCs and iPSCs (SSEA-3, SSEA-4, TRA-1-60, TRA-1-81). Porcine ICM and epiblast express SSEA-1, while expression of human-specific surface markers was found solely in trophoblast which points to the similarities with the naïve state of mouse ESCs and iPSCs (Hall and Hyttel, 2014, Hall et al., 2010). However, the germline transmission of porcine ESCs has not been proven up to date, therefore these cell lines do not fulfil the definition of true ESCs.

\section{The rabbit as a model in biomedical studies}

The rabbit (Oryctolagus cuniculus) is a eutherian mammal belonging to the order Lagomorpha, family Leporidae. It is considered a laboratory and a farm animal, as well as a pet. Lagomorphs are genetically close to primates, and some researchers even suggest their close evolutional relation (Allard et al., 1996, Graur et al., 1996). Rabbit stands out among non-rodent mammals used in research: it is relatively small compared to other livestock species, and it has been of interest to breeders for many generations, resulting in a variety of inbred strains. Its relatively small size, short gestation period (29-31 days), the possibility of setting up timed matings and superovulation, and resilience of the embryos poses the rabbit as an attractive candidate for early embryonic studies. Rabbit embryology resembles that of human in many aspects, notably in the general morphology of peri-gastrulation embryo, which appears in the form of a flat disc, rather than acquiring cupshaped cylinder typical of rodents (Idkowiak et al., 2004). Recent evidence shows that also X chromosome inactivation $(\mathrm{XCl})$ timing and mechanism (linked to the early lineage differentiation) is similar in rabbits and humans. In both species, the Xist homologue is not subjected to imprinting and $\mathrm{XCl}$ begins later than in mice. Xist expression is also upregulated on both $\mathrm{X}$ chromosomes in rabbit and human embryo cells, even in the inner cell mass (Okamoto et al., 2011). Basic embryological and reproductive techniques, such as in vitro culture (Jin et al., 2000, Kane and Foote, 1971, Maurer, 1978, Menezo et al., 1984), in vitro fertilization (Chang, 1959, Pincus and Enzmann, 1934) and cryopreservation (Kasai et al., 1992, Liu et al., 2004, Renard et al., 1984, Tsunoda et al., 1982) have also been established for the rabbit. In fact, the first successful in vitro fertilization in mammals was achieved in rabbit (Chang, 1959, Pincus and Enzmann, 1934), and the first successful embryo transfer was performed in rabbit as early as 1890 by Walter Heape (Biggers, 1991, Heape, 1890, Heape, 1897).

The use of mammals as model organisms in biomedical research depends strongly on the possibility of performing precise genetic engineering such as gene targeting (knock-in, knock-out) and creating reporter lines. Whole genome shotgun sequence at $7.48 x$ coverage is available for the rabbit (OryCun2.0, accession number AAGW02000000). In mice, genetic modifications can be effectively introduced by homologous recombination into ESCs (Bronson and Smithies, 1994), however, germline competent rabbit ESC lines are not yet available. Previously, reporter lines such as Oct4-EGFP have been created by transfection of somatic cells and subsequent somatic cell nuclear transfer (Quan et al., 2014, Yin et al., 2013). Although effective, this method is very time- and labour- consuming. Zinc finger (ZFN) (Kim et al., 1996) and TALEN (Boch, 2011) nucleases have been successfully used for generation of rabbit knockout lines (Flisikowska et al., 2011; Song et al., 2013). Recently, the CRISPR/Cas system has been emerging as an efficient gene-targeting technique with application not limited to cultured cells (Yang et al., 2014). Because of its versatility and specificity, and possibility of precise genome editing in ovo (homologous recombination after injection of gene construct directly into one cell embryo, without the necessity of transfecting cells cultured in vitro), the CRISPR/Cas system opens new avenues for animal 
transgenesis, including wider use of rabbit as model organism in biomedical research (Honda and Ogura, 2017). CRISPR/Cas system has been already used in rabbits to create gene knockouts (Honda et al., 2015, Kawano and Honda, 2017, Xu et al., 2018, Yang et al., 2014) of single or multiple genes (Yan et al., 2014), including creating rabbit models of several muscular dystrophies (Sui, Lau, et al., 2018, Sui, Xu, et al., 2018), as well as targeted rabbit Rosa26 knock-ins (Yang et al., 2016).

Rabbit is also currently used in the studies of atherosclerosis, diabetes, lipoprotein metabolism and cardiovascular diseases (Bosze and Houdebine, 2010, Duranthon et al., 2012, Fischer et al., 2012, Niimi et al., 2016, Püschel et al., 2010). Because of the similarities between rabbit and human embryonic development and placentation, it is a popular model in pregnancy-related conditions, such as testing of developmental toxicity (Bourdon et al., 2018, Martin et al., 2010, Pentsuk and van der Laan, 2009) and maternal Diabetes mellitus (Navarrete Santos et al., 2004 a,b, 2008, Ramin et al., 2010, Thieme et al., 2012). The advance of a novel gene editing techniques will enable the creation of new, more accurate rabbit models for use in biomedical studies.

\section{Preimplantation development of the rabbit embryo and early lineage specification}

Preimplantation period of rabbit embryonic development lasts for 6 days, and at the time of implantation the blastocyst reaches around $5 \mathrm{~mm}$ in diameter and approximately 5000 cells. De novo RNA synthesis is initiated at 2-cell stage, but major genome activation occurs at 8-16 cell stage (Brunet-Simon et al., 2001, Manes, 1973), coincident with degradation of maternal transcripts starting at 8-16 cell stage (Henrion et al., 1997). Importantly, rabbit genome activation is achieved gradually, and maternal to embryonic transition is achieved over several cell cycles, in a manner similar to that observed in human embryos (Braude et al., 1988). As in several other mammalian species, early rabbit embryonic cells exhibit developmental plasticity, and single blastomeres remain totipotent up to 8-cell stage (Moore et al., 1968). Cell polarity is established in rabbit embryos just prior to cavitation, at 32-64-cell morula stage (Koyama et al., 1994, Ziomek et al., 1990), as shown by polarised localization of the microvilli at the surface of the outside cells.

A number of transcription factors that have been associated with pluripotency in the mouse, human, and livestock embryos, are also expressed in the rabbit. OCT4 is expressed throughout the whole preimplantation period, from a zygote to an implanting blastocyst at $6 \mathrm{dpc}$, although the expression level decreases over time, as evidenced by mRNA expression analysis (Henderson et al., 2014, Kobolak et al., 2009, Mamo et al., 2008, Táncos et al., 2015), immunofluorescent labelling (Canon et al., 2018, Henderson et al., 2014, Yin et al., 2013), and expression of GFP reporters (Quan et al., 2014, Yin et al., 2013). Recent evidence has shown that the decrease might be related to progressive methylation of the 5' regulatory region of $P O U 5 F 1$ and its gradual repression in the rabbit TE (Canon et al., 2018). Krüppel-like factor 4 (KLF4) is also expressed in rabbit preimplantation embryos (Henderson et al., 2014, Táncos et al., 2015) and embryo-derived stem cells (Táncos et al., 2017). It has also been shown that overexpression of human $K L F 2$ and KLF4 transcripts in rabbit iPSCs induces their reprogramming towards pluripotency (Tapponnier et al., 2017). SOX2 is chiefly ICM- and EPI-specific in rabbit embryos, and is found in nuclei only starting from mid-blastocyst stage (Henderson et al., 2014, Piliszek et al., 2017, Táncos et al., 2015) similarly to porcine (Hall et al., 2009, Liu et al., 2015) and equine embryos (Iqbal et al., 2014). Expression of a key pluripotency factor NANOG (Chambers et al., 2003) is initiated in the rabbit embryo at 2-cell stage, and expressed throughout the preimplantation period (Henderson et al., 2014, Táncos et al., 2015), but becomes strictly EPI-specific only upon EPI compartment sorting around 4 dpc. Interestingly, although OCT4, SOX2, KLF4 and C-MYC epitope regions show high homology between rabbit and human, only low homology has been observed in case of NANOG (Táncos et al., 2015).

TE differentiation in the rabbit shows certain similarities to other non-rodent mammals. CDX2 is a transcription factor associated with TE, as in the mouse (Strumpf et al., 2005) and other mammals (Berg et al., 2011, Madeja et al., 2013). However, in the rabbit (Piliszek, unpublished data), and pig embryos (Bou et al., 2017, Liu et al., 2015) CDX2 is not expressed at morula and early blastocyst stage (the specific mRNA and protein are first detected only after the blastocyst cavity has been established), while human expanded blastocysts have no nuclear-localised CDX2 signal (Deglincerti et al., 2016). Additionally, OCT4 downregulation appears to be dispensable for TE specification in non-rodent mammals, because prolonged OCT4 expression in the TE and colocalization with CDX2 can be observed in rabbit (Kobolak et al., 2009, Piliszek, unpublished data) as well as human (Kirchhof et al., 2000), bovine (Berg et al., 2011, Kuijk et al., 2008, Madeja et al., 2013), horse (Choi et al., 2009, lqbal et al., 2014) and dog embryos (Wilcox et al., 2009). A similar, prolonged expression of PrE-associated transcription factor GATA6 in TE is found in both rabbit (Piliszek et al., 2017) and human (Deglincerti et al., 2016) embryos up until day 6 of development. It should be noted that the expression (mRNA) of OCT4, KLF4, NANOG and SOX2 is significantly higher in in vitro-cultured rabbit embryos than in their in vivo derived counterparts, potentially suggesting impaired differentiation towards extraembryonic lineages in vitro (Henderson et al., 2014).

Mutual repression of Gata6 and Nanog has been suggested by many authors as a mechanism driving the differentiation of PrE and EPI in the mouse (Bessonnard et al., 2014, Frankenberg et al., 2011, Singh et al., 2007). In the rabbit embryos, GATA6 becomes downregulated in a subset of ICM cells around mid-blastocyst stage, but NANOG is found in all ICM cells at this stage, up until the final differentiation and segregation of PrE and EPI layers (Piliszek et al., 2017), suggesting that the mechanism of PrE versus EPI specification might rely on additional factors. Other lineage-associated transcription factors, SOX2 (EPI) and SOX17 (PrE) show a much more restricted expression pattern in the rabbit embryo. Their expression is initiated at the mid-blastocyst stage, and from the onset is partially mutually exclusive, although a bi-positive cell population can be detected at this stage (Piliszek et al., 2017).

In the mouse embryo, it has been extensively shown that PrE versus EPI specification depends on the activity of FGF/MEK/ERK signalling (Kang et al., 2013, Nichols et al., 2009, Yamanaka et al., 2010). In other mammals, a modification of this pathway activity has varying effects. In human embryos, the specification of PrE is not affected by inactivation of FGF/MEK/ERK pathway (Kuijk et al., 2012; Roode et al., 2012). In the rabbit, similarly to the mouse, the activity of the MEK/ERK signalling pathway is necessary and sufficient to trigger cell differentiation towards the PrE (Piliszek et al., 2017). Blocking of MEK/ERK signalling is also sufficient for 
ablation of PrE in the rabbit. The remaining SOX2-positive EPI cells, unlike in mouse embryos, do not express the high NANOG levels characteristic for the naïve pluripotency (Nichols et al., 2009; Piliszek et al., 2017), which might potentially explain the differences in the derivation of pluripotent stem cell lines from mouse and rabbit embryos.

\section{Derivation of rabbit pluripotent stem cell lines}

Establishment of naïve pluripotent rabbit ESCs is of great interest because of their potential use in basic research, derivation of transgenic animals, and as a model in the establishment of stem-cell based therapies for human and animal medicine. Many research groups have reported derivation of rabbit ESCs or stemlike cells (Fang et al., 2006, Graves and Moreadith, 1993, Honda et al., 2008, Honda et al., 2009, Honda, 2013, Intawicha et al., 2009, Moreadith and Graves, 1992, Osteil et al., 2016, Wang et al., 2007, Zakhartchenko et al., 2011). Currently available rabbit ESCs are morphologically and molecularly different from mouse ESCs, however, they share many characteristics with human, primate and other non-rodent ESCs (du Puy et al., 2011, Tan et al., 2011). Several features indicate that non-rodent ESCs exhibit primed- rather than the naïve state of pluripotency (Nichols and Smith, 2009), and are functional counterparts of mouse EpiSCs, rather than ESCs (Greber et al., 2010). Indeed, they express pluripotency factors typical of mouse primed epiblast cells (Osteil et al., 2013, Schmaltz-Panneau et al., 2014). Primate and rabbit ESC lines also share the ability to differentiate into TE, while it is lost in mouse ESCs (Ginis et al., 2004, Tan et al., 2011). To maintain their characteristics, rabbit and human ESCs require FGF2 and Activin/ Nodal, and not LIF (Ginis et al., 2004, Honda et al., 2009, Hsieh et al., 2011, Wang et al., 2007), while mouse ESC lines cultured without a feeder layer require LIF (Ginis et al., 2004, Wang et al., 2007). In a recent study, Osteil and colleagues meticulously analysed several rabbit ESC derivation conditions, including variations of dissociation methods and culture media, revealing a range of pluripotency states that cell lines acquire in vitro (Osteil et al., 2016). Similar to human ESCs and mouse EpiSCs, rabbit ESCs are rarely able to colonize the ICM in chimaeras and do not contribute to the germline. The most successful rabbit ESC integration so far was shown by Zakharchenko and colleagues, who obtained one life born animal (out of 198 chimaeric embryos), of confirmed somatic chimaerism, which died 60 days after birth, and therefore germline transmission was never assessed (Zakhartchenko et al., 2011). Other researchers reported a rapid loss of chimaerism in rabbit preimplantation embryos after the introduction of rabbit ESCs or iPSCs (Osteil et al., 2013, Osteil et al., 2016, Tapponnier et al., 2017). Existing rabbit ESC lines are nonetheless capable of self-renewal over several passages, exhibit normal karyotype, and are well characterised by the gene expression profiling, teratoma formation and differentiation into derivatives of three germ layers in vitro (Honda et al., 2009, Osteil et al., 2013, Osteil et al., 2016., Wang et al., 2007). Several groups have also reported derivation of rabbit iPSCs, which share similar properties (Honda et al., 2010, Táncos et al., 2017, Tapponnier et al., 2017).

Although mouse-like, naïve pluripotent embryonic or induced stem cells are not available in rabbit, the existing cell lines are more representative of other non-rodent mammalian cell lines, including human. They can be differentiated in vitro towards endoderm, epiblast and mesoderm derivative tissues, and in combination with an increasing number of rabbit disease model lines, present an attractive model for testing efficiency and safety of stem-cell based therapies.

\section{Conclusions}

To broaden our understanding of the basic mechanisms underlying mammalian development and differentiation it is necessary to access the data from phylogenetically different groups of mammals. The increasing interest in farm animal research (large animal models) not only expands our knowledge of the cellular and the molecular mechanisms of development through comparative studies but also equips us with better tools for biomedical research. Bearing in mind the complexity of mammalian preimplantation development and species-specific differences, it is advisory not to concentrate on a limited number of model species to study human (or other species) early embryonic development, but to divide these processes into specific stages/events, and for each find the appropriate counterpart.

\section{Acknowledgements}

This work was supported by National Science Centre, Poland grants no 2017/26/E/NZ3/01205 (AP), 2014/13/D/NZ2/03901 (PP) and 2012/03/B/ NZ9/03349 (ZEM).

\section{References}

AKAGI, S., GESHI, M. and NAGAI, T. (2013). Recent progress in bovine somatic cell nuclear transfer. Anim Sci J 84: 191-199.

ALLARD MW, MCNIFF BE, MIYAMOTOMM (1996). Support for interordinal eutherian relationships with an emphasis on primates and their archontan relatives. $\mathrm{Mol}$ Phylogenet Evol 5: 78-88.

ANDERSON, L.L. (1978). Growth, protein content and distribution of early pig embryos. Anat Rec 190: 143-153.

AOKI, F., WORRAD, D.M. and SCHULTZ, R.M. (1997). Regulation of Transcriptional Activity during the First and Second Cell Cycles in the Preimplantation Mouse Embryo. Dev Biol 181: 296-307.

BAGG, M.A., NOTTLE, M.B., ARMSTRONG, D.T., GRUPEN, CH.G. (2007). Relationship between follicle size and oocyte developmental competence in prepubertal and adult pigs. Reprod Fertil Dev 19: 797-803.

BAHR, A., WOLF, E (2012) Domestic Animal Models for biomedical research. Reprod Dom Anim 47 (Suppl 4): 59-71.

BAZER, F.W. and JOHNSON, G.A. (2014). Pig blastocyst-uterine interactions. Differentiation 87: 52-65.

BEEBE, L.F.S., MCILFATRICK, S.J. and NOTTLE, M.B. (2009). Cytochalasin B and Trichostatin A Treatment Postactivation Improves In vitro Development of Porcine Somatic Cell Nuclear Transfer Embryos. Cloning Stem Cell. 11: 477-482.

BERG, D.K., SMITH, C.S., PEARTON, D.J., WELLS, D.N., BROADHURST, R., DONNISON, M. and PFEFFER, P.L. (2011). Trophectoderm lineage determination in cattle. Dev Cell 20: 244-255.

BERG, D.K., VAN LEEUWEN, J., BEAUMONT, S., BERG, M. and PFEFFER, P.L. (2010). Embryo loss in cattle between Days 7 and 16 of pregnancy. Theriogenology 73: 250-260.

BESSONNARD S, DE MOT L, GONZE D, BARRIOL M, DENNIS C, GOLDBETER A, DUPONT G, CHAZAUD C (2014). Gata6, Nanog and Erk signaling control cell fate in the inner cell mass through a tristable regulatory network. Development 141: 3637-3648.

BIGGERS JD (1991). Walter Heape, FRS: a pioneer in reproductive biology. Centenary of his embryo transfer experiments. J Reprod Fertil 93: 173-186.

BINDON, B. (1971). Systematic Study of Preimplantation Stages of Pregnancy in the Sheep. Aust J Biol Sci 24: 131-148. 
BISSON, L.J., MANOHAR, L.M., WILKINS, R.D., GURSKE-DEPERIO, J., EHRENSBERGER, M.T., 2008: Influence of suture material on the biomechanical behavior of suture-tendon specimens: a controlled study in bovine rotator cuff. Am J Sports Med 36, 907-912.

BOCH J (2011). TALEs of genome targeting. Nat Biotechnol 29: 135-136.

BOGLIOTTI, Y.S., WU, J., VILARINO, M., OKAMURA, D., SOTO, D.A., ZHONG, C., SAKURAI, M., SAMPAIO, R.V., SUZUKI, K., IZPISUA BELMONTE, J.C. et al., (2018). Efficient derivation of stable primed pluripotent embryonic stem cells from bovine blastocysts. Proc Natl Acad Sci USA 115: 2090-2095.

BOSZE Z, HOUDEBINE LM (2010). Application of rabbits in biomedical research: A review. World Rabbit Sci 14: 1-14

BOU G, LIU S, SUN M, ZHU J, XUE B, GUO J, ZHAO Y, QU B, WENG X, WEI Y, LEI L, LIU Z (2017). CDX2 is essential for cell proliferation and polarity in porcine blastocysts. Development 144: 1296-1306.

BOURDON M, TORRES-ROVIRA L, MONNIAUX D, FAURE C, LEVY R, TARRADE A, ROUSSEAU-RALLIARD D, CHAVATTE-PALMERP, JOLIVET G (2018). Impact of a gestational exposure to diesel exhaust on offspring gonadal development: experimental study in the rabbit. J Dev Orig Health Dis: 1-11.

BRAUDE P, BOLTON V, MOORE S (1988). Human gene expression first occurs between the four- and eight-cell stages of preimplantation development. Nature 332: 459-461.

BREVINI TA, VASSENA R, FRANCISCI C, GANDOLFI F. (2005) Role of adenosine triphosphate, active mitochondria, and microtubules in the acquisition of developmental competence of parthenogenetically activated pig oocytes. Biol Reprod. 72: 1218-1223.

BREVINI, T.A.L., PENNAROSSA, G., ANTONINI, S. and GANDOLFI, F. (2008). Parthenogenesis as an approach to pluripotency: Advantages and limitations involved. Stem Cell Rev 4: 127-135.

BREVINI, T.A., PENNAROSSA, G., ATTANASIO, L., VANELLI, A., GASPARRINI, B. and GANDOLFI, F. (2010). Culture conditions and signalling networks promoting the establishment of cell lines from parthenogenetic and biparental pig embryos. Stem Cell Rev 6: 484-495.

BREVINI, T.A., PENNAROSSA, G., MAFFEI, S. and GANDOLFI, F. (2012). Pluripotency Network in Porcine Embryos and Derived Cell Lines. Reprod Domest Anim 47: 86-91.

BRONSON SK, SMITHIES O (1994). Altering mice by homologous recombination using embryonic stem cells. J Biol Chem 269: 27155-27158.

BRUNET-SIMON A, HENRION G, RENARD JP, DURANTHON V (2001). Onset of zygotic transcription and maternal transcript legacy in the rabbit embryo. Mol Reprod Dev 58: 127-136.

BUEHR, M. (2002). Rapid Loss of Oct-4 and Pluripotency in Cultured Rodent Blastocysts and Derivative Cell Lines. Biol Reprod 68: 222-229.

BUEHR, M., MEEK, S., BLAIR, K., YANG, J., URE, J., SILVA, J., MCLAY, R., HALL, J., YING, Q.L. and SMITH, A. (2008). Capture of authentic embryonic stem cells from rat blastocysts. Cell 135: 1287-1298.

BURRUEL, V., KLOOSTER, K., BARKER, C.M., PERA, R.R. and MEYERS, S. (2014). Abnormal early cleavage events predict early embryo demise: sperm oxidative stress and early abnormal cleavage. Sci Rep 4: 6598.

CALLESEN, H., LIU, Y., PEDERSEN, H.S., SCHMIDT, M. (2014). Increasing efficiency in production of cloned piglets. Cell Reprogram 16: 407-410.

CANON E, JOUNEAU L, BLACHÈRE T, PEYNOT N, DANIEL N, BOULANGER L, MAULNY L, ARCHILLA C, VOISIN S, JOUNEAU A, GODET M, DURANTHON V (2018). Progressive methylation of POU5F1 regulatory regions during blastocyst development. Reproduction 156: 145-161.

CASSER, E., ISRAEL, S., WITTEN, A., SCHULTE, K., SCHLATT, S., NORDHOFF, V. and BOIANI, M. (2017). Totipotency segregates between the sister blastomeres of two-cell stage mouse embryos. Sci Rep 7: 8299.

CHAMBERS I, COLBYD, ROBERTSON M, NICHOLS J, LEE S, TWEEDIE S, SMITH $A(2003)$. Functional expression cloning of Nanog, a pluripotency sustaining factor in embryonic stem cells. Cell 113: 643-655.

CHANG, M.C. (1954). Development of parthenogenetic rabbit blastocysts induced by low temperature storage of unfertilized ova. J Exp Zool 125: 127-149.

CHANG MC (1959). Fertilization of rabbit ova in vitro. Nature 184(Suppl 7): 466-467.

CHAVEZ, S.L., LOEWKE, K.E., HAN, J., MOUSSAVI, F., COLLS, P., MUNNE, S., BEHR, B. and REIJO PERA, R.A. (2012). Dynamic blastomere behaviour reflects human embryo ploidy by the four-cell stage. Nat Commun 3: 1251 .

CHAZAUD, C. and YAMANAKA, Y. (2016). Lineage specification in the mouse preimplantation embryo. Development 143: 1063-1074.

CHAZAUD, C., YAMANAKA, Y., PAWSON, T. and ROSSANT, J. (2003). Early Lineage Segregation between Epiblast and Primitive Endoderm in Mouse Blastocysts through the Grb2-MAPK Pathway. Dev Cell 10: 615-624.

CHEN, CH.Y., CHENG, Y.Y., Yen, CH.Y., Hsieh, P.C.H. (2017). Mechanisms of pluripotency maintenance in mouse embryonic stem cells. Cell Mol Life Sci74:1805-1817

CHEN, L.R., SHIUE, Y.L., BERTOLINI, L., MEDRANO, J.F., BONDURANT, R.H. and ANDERSON, G.B. (1999). Establishment of pluripotent cell lines from porcine preimplantation embryos. Theriogenology 52: 195-212.

CHEN, Q., SHI, J., TAO, Y. and ZERNICKA-GOETZ, M. (2018). Tracing the origin of heterogeneity and symmetry breaking in the early mammalian embryo. Nat Commun 9: 1819.

CHOI YH, HARDING HD, HARTMAN DL, OBERMILLER AD, KUROSAKA S, MCLAUGHLIN KJ, HINRICHS K (2009). The uterine environment modulates trophectodermal POU5F1 levels in equine blastocysts. Reproduction 138:589-599.

CIBELLI, J.B., GRANT, K.A., CHAPMAN, K.B., CUNNIFF, K., WORST, T., GREEN, H.L., WALKER, S.J., GUTIN, P.H., VILNER, L., TABAR, V. et al., (2002). Parthenogenetic Stem Cells in Nonhuman Primates. Science 295: 819-819.

DEGLINCERTI A, CROFT GF, PIETILA LN, ZERNICKA-GOETZ M, SIGGIA ED, BRIVANLOU AH (2016). Self-organization of the in vitro attached human embryo. Nature 533: 251-254.

DEGRELLE, S.A., CAMPION, E., CABAN, C., PIUMI, F., REINAUD, P., RICHARD, C., RENARD, J.P. and HUE, I. (2005). Molecular evidence for a critical period in mural trophoblast development in bovine blastocysts. Dev Biol 288: 448-460.

DENICOL, A.C., DOBBS, K.B., MCLEAN, K.M., CARAMBULA, S.F., LOUREIRO, B. and HANSEN, P.J. (2013). Canonical WNT signaling regulates development of bovine embryos to the blastocyst stage. Sci Rep 3: 1266.

DU PUY, L., CHUVA DE SOUSA LOPES, S.M., HAAGSMAN, H.P. and ROELEN, B.A.J. (2011). Analysis of co-expression of OCT4, NANOG and SOX2 in pluripotent cells of the porcine embryo, in vivo and in vitro. Theriogenology 75: 513-526.

DURANTHON V, BEAUJEAN N, BRUNNER M, ODENING KE, SANTOS AN, KACSKOVICS I, HIRIPI L, WEINSTEIN EJ, BOSZE Z (2012). On the emerging role of rabbit as human disease model and the instrumental role of novel transgenic tools. Transgenic Res 21: 699-713.

ELLISH, N.J., SABODA, K., O'CONNOR, J., NASCA, P.C., STANEK, E.J. and BOYLE, C. (1996). A prospective study of early pregnancy loss. Hum Reprod 11: 406-412.

EVANS, M.J. and KAUFMAN, M.H. (1981). Establishment in culture of pluripotential cells from mouse embryos. Nature 292: 154-156.

EVANS, M.J., NOTARIANNI, E., LAURIE, S. and MOOR, R.M. (1990). Derivation and preliminary characterization of pluripotent cell lines from porcine and bovine blastocysts. Theriogenology 33: 125-128.

EZASHI, T., YUAN, Y. and ROBERTS, R.M. (2016). Pluripotent Stem Cells from Domesticated Mammals. Annu Rev Anim Biosci 4: 223-253.

FANG ZF, GAI H, HUANG YZ, LI SG, CHEN XJ, SHI JJ, WU L, LIU A, XU P, SHENG $\mathrm{HZ}$ (2006). Rabbit embryonic stem cell lines derived from fertilized, parthenogenetic or somatic cell nuclear transfer embryos. Exp Cell Res 312: 3669-3682.

FISCHER B, CHAVATTE-PALMER P, VIEBAHN C, SANTOS AN, DURANTHON V (2012). Rabbit as a reproductive model for human health. Reproduction 144:1-10.

FLISIKOWSKAT, THOREYIS, OFFNERS, ROSF, LIFKE V, ZEITLERB, ROTTMANN O, VINCENTA, ZHANG L, JENKINS S, NIERSBACH H, KIND AJ, GREGORYPD, SCHNIEKEAE, PLATZER J (2011). Efficient immunoglobulin gene disruption and targeted replacement in rabbit using zinc finger nucleases. PloS One 6: e21045.

FOGARTY, N.M.E., MCCARTHY,A., SNIJDERS, K.E., POWELL, B.E., KUBIKOVA, N., BLAKELEY, P., LEA, R., ELDER, K., WAMAITHA, S.E., KIM, D. et al., (2017). Genome editing reveals a role for OCT4 in human embryogenesis. Nature 550:67-73.

FRANKENBERG S, GERBE F, BESSONNARD S, BELVILLE C, POUCHIN P, BARDOT O, CHAZAUD C (2011). Primitive endoderm differentiates via a three-step mechanism involving Nanog and RTK signaling. Dev Cell 21: 1005-1013.

GIL MA, RUIZ M, VAZQUEZ JM, ROCA J, DAY BN, MARTINEZ EA. (2004) Effect of short periods of sperm-oocyte coincubation during in vitro fertilization on embryo development in pigs. Theriogenology 62: 544-552.

GINIS I, LUO Y, MIURA T, THIES S, BRANDENBERGER R, GERECHT-NIR S, AMIT M, HOKE A, CARPENTER MK, ITSKOVITZ-ELDOR J, RAO MS (2004). Differ- 
ences between human and mouse embryonic stem cells. Dev Biol 269: 360-380. GRAHAM, C.F. (1970). Parthenogenetic mouse blastocysts. Nature 226: 165-167. GRAURD, DURETL, GOUYM (1996). Phylogenetic position of the order Lagomorpha (rabbits, hares and allies). Nature 379: 333-335.

GRAVES KH, MOREADITH RW (1993). Derivation and characterization of putative pluripotential embryonic stem cells from preimplantation rabbit embryos. $\mathrm{Mol}$ Reprod Dev 36: 424-433.

GREBER B, WU G, BERNEMANN C, JOO JY, HAN DW, KO K, TAPIA N, SABOUR D, STERNECKERT J, TESAR P, SCHÖLER HR (2010). Conserved and divergent roles of FGF signaling in mouse epiblast stem cells and human embryonic stem cells. Cell Stem Cell 6: 215-226.

GRUPEN CG, MAU JC, MCLLFATRICK SM, MADDOCKS S, NOTTLE MB. (2002) Effect of 6-dimethylaminopurine on electrically activated in vitro matured porcine oocytes. Mol Reprod Dev. 62: 387-396.

GRUPEN, CH.G.,ARMSTRONG D.T. (2010). Relationship between cumulus cell apoptosis, progesterone production and porcine oocyte developmental competence: temporal effects of follicular fluid during IVM. Reprod Fertil Dev 22: 1100-1109.

GUO, G., YANG, J., NICHOLS, J., HALL, J.S., EYRES, I., MANSFIELD, W. and SMITH, A. (2009). Klf4 reverts developmentally programmed restriction of ground state pluripotency. Development 136: 1063-1069.

HALL VJ, CHRISTENSEN J, GAO Y, SCHMIDT MH, HYTTEL P (2009). Porcine pluripotency cell signaling develops from the inner cell mass to the epiblast during early development. Dev Dyn 238: 2014-2024.

HALL VJ, HYTTEL P (2014). Breaking down pluripotency in the porcine embryo reveals both a premature and reticent stem cell state in the inner cell mass and unique expression profiles of the naive and primed stem cell states. Stem Cells Dev 23: 2030-2045.

HALL, V.J., JACOBSEN, J.V., RASMUSSEN, M.A. and HYTTEL, P. (2010). Ultrastructural and molecular distinctions between the porcine inner cell mass and epiblast reveal unique pluripotent cell states. Dev Dyn 239: 2911-2920.

HAMMER, R.E., PURSEL, V.G., REXROAD, C.E. JR, WALL, R.J., BOLT, D.J., EBERT, K.M., PALMITER, R.D., BRINSTER, R.L. (1985). Production of transgenic rabbits, sheep and pigs by microinjection. Nature 315, 680-683.

HAN, X., OUYANG, H., CHEN, X., HUANG, Y., SONG, Y., ZHANG, M., PANG, D., LAI, L. and LI, Z. (2013). Aberrant expression of Igf2/H19 in porcine parthenogenetic fetuses and placentas. Anim Reprod Sci 139: 101-108.

HARAGUCHI, S., KIKUCHI, K., NAKAI, M. and TOKUNAGA, T. (2012). Establishment of Self-renewing Porcine Embryonic Stem Cell-like Cells by Signal Inhibition. $J$ Reprod Dev 58: 707-716.

HEAPE W (1890). Preliminary note on the transplantation and growth of mammalian ova within a uterine foster mother. Proc $R$ Soc Lond Biol Sci 48: 457-459.

HEAPE W (1897). Further note on transplantation and growth of mammalian ova within a uterine foster-mother. Proc R Soc Lond Biol Sci 62: 178-183.

HENDERSON GRW, BRAHMASANI SR, YELISETTI UM, KONIJETI S, KATARI VC, SISINTHY S (2014). Candidate gene expression patterns in rabbit preimplantation embryos developed in vivo and in vitro. J Assist Reprod Genet 31: 899-911.

HENRION G, BRUNET A, RENARD JP, DURANTHON V (1997). Identification of maternal transcripts that progressively disappear during the cleavage period of rabbit embryos. Mol Reprod Dev 47: 353-362.

HERATH, S., DOBSON, H., BRYANT, C.E., SHELDON, I.M., 2006: Use of the cow as a large animal model of uterine infection and immunity. J Reprod Immunol69: 13-22.

HONDA A (2013). Isolation and culture of rabbit embryonic stem cells. Methods Mol Biol 1074: 39-49.

HONDA A, HIROSE M, HATORI M, MATOBA S, MIYOSHI H, INOUE K, OGURA A (2010). Generation of Induced Pluripotent Stem Cells in Rabbits. J Biol Chem 285: 31362-31369.

HONDA A, HIROSE M, INOUE K, OGONUKI N, MIKI H, SHIMOZAWA N, HATORI M, SHIMIZU N, MURATA T, HIROSE Megumi, KATAYAMA K, WAKISAKA N, MIYOSHI H, YOKOYAMA KK, SANKAI T, OGURA A (2008). Stable embryonic stem cell lines in rabbits: potential small animal models for human research. Reprod Biomed Online 17: 706-715.

HONDA A, HIROSE M, OGURA A (2009). Basic FGF and Activin/Nodal but not LIF signaling sustain undifferentiated status of rabbit embryonic stem cells. Exp Cell Res 315: 2033-2042.

HONDAA, HIROSE M, SANKAI T, YASMIN L, YUZAWA K, HONSHO K, IZU H, IGU-
CHI A, IKAWA M, OGURA A (2015). Single-step generation of rabbits carrying a targeted allele of the tyrosinase gene using CRISPR/Cas9. Exp Anim 64: 31-37.

HONDA A, OGURA A (2017). Rabbit models for biomedical research revisited via genome editing approaches. J Reprod Dev 63: 435-438.

HSIEH Y-C, INTAWICHAP, LEE K-H, CHIU Y-T, LO N-W, JU J-C (2011). LIF and FGF Cooperatively Support Stemness of Rabbit Embryonic Stem Cells Derived from Parthenogenetically Activated Embryos. Cell Reprogram 13: 241-255.

IDKOWIAK J, WEISHEIT G, PLITZNER J, VIEBAHN C (2004). Hypoblast controls mesoderm generation and axial patterning in the gastrulating rabbit embryo. Dev Genes Evol 214: 591-605.

INTAWICHA P, OU Y-W, LO N-W, ZHANG S-C, CHEN Y-Z, LIN T-A, SU H-L, GUU H-F, CHEN M-J, LEE K-H, CHIU Y-T, JU J-C (2009). Characterization of embryonic stem cell lines derived from New Zealand white rabbit embryos. Cloning Stem Cells 11: 27-38.

IQBAL K, CHITWOOD JL, MEYERS-BROWN GA, ROSER JF, ROSS PJ (2014) RNA-seq transcriptome profiling of equine inner cell mass and trophectoderm. Biol Reprod 90: 61.

JIN DI, KIM DK, IM KS, CHOI WS (2000). Successful pregnancy after transfer of rabbit blastocysts grown in vitrofrom single-cell zygotes. Theriogenology 54:1109-1116.

JOHNSON, W.H., LOSKUTOFF, N.M., PLANTE, Y. and BETTERIDGE, K.J. (1995). Production of four identical calves by the separation of blastomeres from an in vitro derived four-cell embryo. Vet Rec 137: 15-16.

KANE MT, FOOTE RH (1971). Factors affecting blastocyst expansion of rabbit zygotes and young embryos in defined media. Biol Reprod 4: 41-47.

KANG M, PILISZEK A, ARTUS J, HADJANTONAKIS A-K (2013). FGF4 is required for lineage restriction and salt-and-pepper distribution of primitive endoderm factors but not their initial expression in the mouse. Development 140: 267-279.

KASAI M, HAMAGUCHIY, ZHU SE, MIYAKE T, SAKURAI T, MACHIDAT (1992). High survival of rabbit morulae after vitrification in an ethylene glycol-based solution by a simple method. Biol Reprod 46: 1042-1046.

KATAYAMA, M., ELLERSIECK, M.R. and ROBERTS, R.M. (2010). Development of monozygotic twin mouse embryos from the time of blastomere separation at the two-cell stage to blastocyst. Biol Reprod 82: 1237-1247.

KAUFMAN, M.H. (1995). The Atlas of Mouse Development. Academic Press London.

KAUFMAN, M.H. and GARDNER, R.L. (1974). Diploid and haploid mouse parthenogenetic development following in vitro activation and embryo transfer. J Embryol Exp Morphol 31: 635-642.

KAWANO Y, HONDA A (2017). Gene Targeting in Rabbits: Single-Step Generation of Knock-out Rabbits by Microinjection of CRISPR/Cas9 Plasmids. Methods Mol Biol 1630: 109-120

KIM, E., HWANG, S.-U., YOO, H., YOON, J.D., JEON, Y., KIM, H., JEUNG, E.-B., LEE, C.-K. and HYUN, S.-H. (2016). Putative embryonic stem cells derived from porcine cloned blastocysts using induced pluripotent stem cells as donors. Theriogenology 85: 601-616.

KIM, E.Y., PARK, M.J., PARK, H.Y., NOH, E.J., NOH, E.H., PARK, K.S., LEE, J.B., JEONG, C.J., RIU, K.Z. and PARK, S.P. (2012). Improved cloning efficiency and developmental potential in bovine somatic cell nuclear transfer with the oosight imaging system. Cell Reprogram 14: 305-311.

KIM, K., LEROU, P., YABUUCHI, A., LENGERKE, C., NG, K., WEST, J., KIRBY, A., DALY, M.J. and DALEY, G.Q. (2007). Histocompatible Embryonic Stem Cells by Parthenogenesis. Science 315: 482-486.

KIM, K.T., STREIJGER, F., MANOUCHEHRI, N., SO, K., SHORTT, K., OKON, E.B., TIGCHELAAR, S., CRIPTON, P., KWON, B.K. (2018) Review of the UBC Porcine Model of Traumatic Spinal Cord Injury. J Korean Neurosurg Soc. 61(5):539-547.

KIM YG, CHA J, CHANDRASEGARAN S (1996). Hybrid restriction enzymes: zinc finger fusions to Fok I cleavage domain. Proc Natl Acad Sci USA 93: 1156-1160.

KIRCHHOF N, CARNWATH JW, LEMME E, ANASTASSIADIS K, SCHÖLER H, NIEMANN H (2000). Expression pattern of Oct-4 in preimplantation embryos of different species. Biol Reprod 63: 1698-1705.

KISHIGAMI, S., MIZUTANI, E., OHTA, H., HIKICHI, T., THUAN, N.V., WAKAYAMA S., BUI, H.-T. and WAKAYAMA, T. (2006). Significant improvement of mouse cloning technique by treatment with trichostatin $A$ after somatic nuclear transfer. Biochem. Biophys. Res. Commun. 340: 183-189.

KOBOLAK J, KISS K, POLGAR Z, MAMO S, ROGEL-GAILLARD C, TANCOS Z, BOCK I, BAJI AG, TAR K, PIRITY MK, DINNYES A (2009). Promoter analysis of 
the rabbit POU5F1 gene and its expression in preimplantation stage embryos. BMC Mol Biol 10: 88

KONO, T., OBATA, Y., WU, Q., NIWA, K., ONO, Y., YAMAMOTO, Y., PARK, E.S., SEO, J.-S. and OGAWA, H. (2004). Birth of parthenogenetic mice that can develop to adulthood. Nature 428: 860.

KOYAMA H, SUZUKI H, YANG X, JIANG S, FOOTE RH (1994). Analysis of polarity of bovine and rabbit embryos by scanning electron microscopy. Biol Reprod 50: 163-170.

KUIJK EW, DU PUY L, VANTOLHTA, OEI CHY, HAAGSMAN HP, COLENBRANDER $B, R O E L E N$ BAJ (2008). Differences in early lineage segregation between mammals. Dev Dynamics 237: 918-927.

KUIJK EW, VAN TOL LTA, VAN DE VELDE H, WUBBOLTS R, WELLING M, GEIJSEN N, ROELEN BAJ (2012). The roles of FGF and MAP kinase signaling in the segregation of the epiblast and hypoblast cell lineages in bovine and human embryos. Development 139: 871-882.

LANNER, F. and ROSSANT, J. (2010). The role of FGF/Erk signaling in pluripotent cells. Development 137: 3351-3360.

LIUJ-L, KUSAKABE H, CHANG C-C, SUZUKIH, SCHMIDTDW, JULIAN M, PFEFFER R, BORMANNCL, TIANXC, YANAGIMACHIR, YANGX(2004). Freeze-dried sperm fertilization leads to full-term development in rabbits. Biol Reprod 70: 1776-1781.

LIU S, BOU G, SUN R, GUO S, XUE B, WEI R, COONEY AJ, LIU Z (2015). Sox2 is the faithful marker for pluripotency in pig: Evidence from embryonic studies. Dev Dyn 244: 619-627.

LOGAN, C.Y. and NUSSE, R. (2004). The Wnt signaling pathway in development and disease. Annu Rev Cell Dev Biol 20: 781-810.

LU, C.W., YABUUCHI, A., CHEN, L., VISWANATHAN, S., KIM, K. and DALEY, G.Q. (2008). Ras-MAPK signaling promotes trophectoderm formation from embryonic stem cells and mouse embryos. Nat Genet 40: 921-926.

MADEJA, Z.E., HRYNIEWICZ, K., ORSZTYNOWICZ, M., PAWLAK, P. and PERKOWSKA, A. (2015). WNT/ $\beta$-catenin signalling affects cell lineage and pluripotency specific gene expression in bovine blastocysts - prospects for bovine ESC derivation. Stem Cells Dev 24: 2437-2454.

MADEJA, Z.E., SOSNOWSKI, J., HRYNIEWICZ, K., WARZYCH, E., PAWLAK, P., ROZWADOWSKA, N., PLUSA, B. and LECHNIAK, D. (2013). Changes in subcellular localisation of trophoblast and inner cell mass specific transcription factors during bovine preimplantation development. BMC Dev Biol 13: 32.

MAI, Q., YU, Y., LI, T., WANG, L., CHEN, M.-J., HUANG, S.-Z., ZHOU, C. and ZHOU, Q. (2007). Derivation of human embryonic stem cell lines from parthenogenetic blastocysts. Cell Res 17: 1008.

MALHI, P.S., ADAMS, G.P., SINGH, J., 2005: Bovine model for the study of reproductive aging in women: follicular, luteal, and endocrine characteristics. Biol Reprod 73, 45-53.

MAMO S, GAL AB, POLGAR Z, DINNYES A (2008). Expression profiles of the pluripotency marker gene POU5F1 and validation of reference genes in rabbit oocytes and preimplantation stage embryos. BMC Mol Biol 9: 67.

MANES C (1973). The participation of the embryonic genome during early cleavage in the rabbit. Dev Biol 32: 453-459.

MARTIN, G.R. (1981). Isolation of a pluripotent cell line from early mouse embryos cultured in medium conditioned by teratocarcinoma stem cells. Proc Natl Acad Sci USA 78: 7634-7638.

MARTINPL, ZHOUZ, VANDENBULCKK, KWOKD, POWERSG, JIAOQ, SCHANTZ A, TREACY G (2010). Pharmacology and placental transfer of a human alphav integrin monoclonal antibody in rabbits. Birth Defects Res B Dev Reprod Toxicol 89: 116-123.

MAURER RR (1978). Advances in Rabbit Embryo Culture. In Methods Mamm. Reprod. 259-272.

MCLEAN, Z., MENG, F., HENDERSON, H., TURNER, P. and OBACK, B. (2014). Increased MAP kinase inhibition enhances epiblast-specific gene expression in bovine blastocysts. Biol Reprod 91: 49.

MENEZO Y, TESTART J, PERRONE D (1984). Serum is not necessary in human in vitro fertilization, early embryo culture, and transfer. Fertil Steril 42: 750-755.

MESEGUER, M., HERRERO, J., TEJERA, A., HILLIGSOE, K.M., RAMSING, N.B. and REMOHI, J. (2011). The use of morphokinetics as a predictor of embryo implantation. Hum Reprod 26: 2658-2671.

MOORE, G.E., ISHIDA, M., DEMETRIOU, C., AL-OLABI, L., LEON, L.J., THOMAS,
A.C., ABU-AMERO, S., FROST, J.M., STAFFORD, J.L., CHAOQUN, Y. et al., (2015). The role and interaction of imprinted genes in human fetal growth. Philos Trans R Soc Lond B Biol Sci. 370: 20140074. doi: 10.1098/rstb.2014.0074

MOORE NW, ADAMS CE, ROWSON LE (1968). Developmental potential of single blastomeres of the rabbit egg. J Reprod Fertil 17: 527-531.

MOREADITH RW, GRAVES KH (1992). Derivation of pluripotential embryonic stem cells from the rabbit. Trans Assoc Am Physicians 105: 197-203.

NAVARRETE SANTOS A, RAMIN N, TONACK S, FISCHER B (2008). Cell lineagespecific signaling of insulin and insulin-like growth factor I in rabbit blastocysts. Endocrinology 149: 515-524.

NAVARRETE SANTOS A, TONACK S, KIRSTEIN M, KIETZ S, FISCHER B (2004). Two insulin-responsive glucose transporter isoforms and the insulin receptor are developmentally expressed in rabbit preimplantation embryos. Reproduction 128: 503-516.

NAVARRETE SANTOS A, TONACK S, KIRSTEIN M, PANTALEON M, KAYE P, FISCHERB (2004). Insulin acts via mitogen-activated protein kinase phosphorylation in rabbit blastocysts. Reproduction 128: 517-526.

NIAKAN, K.K., HAN, J., PEDERSEN, R.A., SIMON, C. and PERA, R.A. (2012). Human pre-implantation embryo development. Development 139: 829-841.

NICHOLS, J., SILVA, J., ROODE, M. and SMITH, A. (2009). Suppression of Erk signalling promotes ground state pluripotency in the mouse embryo. Development 136: 3215-3222

NICHOLS J, SMITH A (2009). Naive and primed pluripotent states. Cell Stem Cell 4: 487-492.

NICHOLS, J., ZEVNIK, B., ANASTASSIADIS, K., NIWA, H., KLEWE-NEBENIUS, D. CHAMBERS, I., SCHOLER, H. and SMITH, A. (1998). Formation of pluripotent stem cells in the mammalian embryo depends on the POU transcription factor Oct4. Cell 95: 379-391.

NIIMI M, YANG D, KITAJIMA S, NING B, WANG C, LI S, LIU E, ZHANG J, EUGENE CHEN Y, FAN J (2016). ApoE knockout rabbits: A novel model for the study of human hyperlipidemia. Atherosclerosis 245: 187-193.

NIWA, H. (2007). Open conformation chromatin and pluripotency. Genes Dev 21 : 2671-2676.

OKAMOTO I, PATRAT C, THÉPOT D, PEYNOT N, FAUQUE P, DANIEL N, DIABANGOUAYA P, WOLF J-P, RENARD J-P, DURANTHON V, HEARD E (2011). Eutherian mammals use diverse strategies to initiate $\mathrm{X}$-chromosome inactivation during development. Nature 472: 370-374.

OSTEIL P, MOULIN A, SANTAMARIA C, JOLY T, JOUNEAU L, AUBRY M, TAPPONNIER Y, ARCHILLA C, SCHMALTZ-PANNEAU B, LECARDONNEL J, et al., (2016). A Panel of Embryonic Stem Cell Lines Reveals the Variety and Dynamic of Pluripotent States in Rabbits. Stem Cell Rep 7: 383-398.

OSTEIL P, TAPPONNIER Y, MARKOSSIAN S, GODET M, SCHMALTZ-PANNEAU B, JOUNEAU L, CABAU C, JOLY T, BLACHĖRE T, GÓCZA E, BERNAT A, YERLE M, ACLOQUE H, HIDOT S, BOSZE Z, DURANTHON V, SAVATIER P, AFANASSIEFF M (2013). Induced pluripotent stem cells derived from rabbits exhibit some characteristics of naïve pluripotency. Biol Open 2: 613-628.

OZAWA, M., SAKATANI, M., HANKOWSKI, K.E., TERADA, N., DOBBS, K.B. and HANSEN, P.J. (2012). Importance of culture conditions during the morula-to-blastocyst period on capacity of inner cell-mass cells of bovine blastocysts for establishment of self-renewing pluripotent cells. Theriogenology 78: 1243-1251 e1-2.

PALMIERI SL, PETER W, HESS H, SCHOLER HR. (1994). Oct-4 transcription factor is differentially expressed in the mouseembryo during establishment of the first two extraembryonic cell lineages involved in implantation. Dev Biol 166: 259-267

PARK, C.-H., KIM, H.-S., LEE, S.-G. and LEE, C.-K. (2009). Methylation status of differentially methylated regions at Igf2/H19 locus in porcine gametes and preimplantation embryos. Genomics 93: 179-186.

PARK, C.-H., UH, K.-J., MULLIGAN, B.P., JEUNG, E.-B., HYUN, S.-H., SHIN, T., KA, H. and LEE, C.-K. (2011). Analysis of Imprinted Gene Expression in Normal Fertilized and Uniparental Preimplantation Porcine Embryos. Plos One 6: e22216.

PASHAIASL, M., KHODADADI, K., RICHINGS, N.M., HOLLAND, M.K. and VERMA, P.J. (2013). Cryopreservation and long-term maintenance of bovine embryo-derived cell lines. Reprod Fertil Dev 25: 707-718.

PAWLAK, P, PERS-KAMCZYC, E, RENSKA, N, KUBICKOVA, S, LECHNIAK D. (2011) Disturbances of nuclear maturation in BCB positive oocytes collected from peri-pubertal gilts. Theriogenology. 75: $832-840$ 
PAWLAK, P., WARZYCH, E., CIESLAK, A., MALYSZKA, N., MACIEJEWSKA, E., MADEJA, Z.E., LECHNIAK, D. (2018). The consequences of porcine IVM medium supplementation with follicular fluid become reflected in embryo quality, yield and gene expression patterns. Sci Rep. 8: 15306.

PEIPPO, J., MACHATY, Z. and PETER,A. (2011). Terminologies for the pre-attachment bovine embryo. Theriogenology 76: 1373-1379.

PENTSUK N, VAN DER LAAN JW (2009). An interspecies comparison of placental antibody transfer: new insights into developmental toxicity testing of monoclonal antibodies. Birth Defects Res B Dev Reprod Toxicol 86: 328-344.

PERLEBERG C, KIND A, SCHNIEKE A (2018). Genetically engineered pigs as models for human disease. Dis Model Mech 11(1). pii: dmm030783. doi: 10.1242/ dmm.030783.

PIEDRAHITA, J.A., ANDERSON, G.B. and BONDURANT, R.H. (1990). Influence of feeder layer type on the efficiency of isolation of porcine embryo-derived cell lines. Theriogenology 34: 865-877.

PILISZEK, A., GRABAREK, J.B., FRANKENBERG, S.R. and PLUSA, B. (2016). Cell fate in animal and human blastocysts and the determination of viability. $\mathrm{Mol}$ Hum Reprod 22: 681-690.

PILISZEK, A. and MADEJA, Z.E. (2018). Pre-implantation Development of Domestic Animals. Curr Top Dev Biol 128: 267-294.

PILISZEKA, MADEJAZE, PLUSAB (2017). Suppression of ERK signalling abolishes primitive endoderm formation but does not promote pluripotency in rabbit embryo. Development 144: 3719-3730

PINCUS G, ENZMANN EV (1934). Can Mammalian Eggs Undergo Normal Development in Vitro? Proc Natl Acad Sci USA 20: 121-122.

PINCUS, G. and SHAPIRO, H. (1940). Further Studies on the Parthenogenetic Activation of Rabbit Eggs. Proc Natl Acad Sci USA 26: 163-165.

PLUSAB, PILISZEKA, FRANKENBERG S, ARTUS J, HADJANTONAKISA-K (2008). Distinct sequential cell behaviours direct primitive endoderm formation in the mouse blastocyst. Development 135: 3081-3091.

PÜSCHEL B, DANIEL N, BITZER E, BLUM M, RENARD J-P, VIEBAHN C (2010). The rabbit (Oryctolagus cuniculus): a model for mammalian reproduction and early embryology. Cold Spring Harb Protoc 2010: pdb.emo139.

QUAN L, CHEN Y, SONG J, YAN Q, ZHANG Q, LAI S, FAN N, XIN J, ZOU Q, LAI L (2014). Establishment of a rabbit Oct4 promoter-based EGFP reporter system. Plos One 9: e109728.

RAMIN N, THIEME R, FISCHER S, SCHINDLER M, SCHMIDT T, FISCHER B, NAVARRETE SANTOS A (2010). Maternal diabetes impairs gastrulation and insulin and IGF-I receptor expression in rabbit blastocysts. Endocrinology 151:4158-4167.

RENARD JP, BUI-XUAN-NGUYEN null, GARNIER V (1984). Two-step freezing of two-cell rabbit embryos after partial dehydration at room temperature. $J$ Reprod Fertil 71: 573-580.

REVAZOVA, E.S., TUROVETS, N.A., KOCHETKOVA, O.D., AGAPOVA, L.S., SEBASTIAN, J.L., PRYZHKOVA, M.V., SMOLNIKOVA, V.I., KUZMICHEV, L.N. and JANUS, J.D. (2008). HLA homozygous stem cell lines derived from human parthenogenetic blastocysts. Cloning Stem Cells 10: 11-24.

REVAZOVA, E.S., TUROVETS, N.A., KOCHETKOVA, O.D., KINDAROVA, L.B., KUZMICHEV, L.N., JANUS, J.D. and PRYZHKOVA, M.V. (2007). Patient-Specific Stem Cell Lines Derived from Human Parthenogenetic Blastocysts. Cloning Stem Cells 9: 432-449.

RODRÍGUEZ, A., ALLEGRUCCI, C. and ALBERIO, R. (2012). Modulation of Pluripotency in the Porcine Embryo and iPS Cells. Plos One 7: e49079.

ROODE M, BLAIR K, SNELL P, ELDER K, MARCHANT S, SMITH A, NICHOLS J (2012). Human hypoblast formation is not dependent on FGF signalling. Dev Biol 361: 358-363.

ROSSANT, J., CHAZAUD, C. and YAMANAKA, Y. (2003). Lineage allocation and asymmetries in the early mouse embryo. Philos Trans $R$ Soc Lond B Biol Sci 358: 1341-1349.

SAIZ, N. and PLUSA, B. (2013). Early cell fate decisions in the mouse embryo. Reproduction 145: R65-80.

SANCHEZ-PERNAUTE, R., LEE, H., PATTERSON, M., RESKE-NIELSEN, C., YOSHIZAKI, T., SONNTAG, K.C., STUDER, L. and ISACSON, O. (2008). Parthenogenetic dopamine neurons from primate embryonic stem cells restore function in experimental Parkinson's disease. Brain 131: 2127-2139.

SATO, N., MEIJER, L., SKALTSOUNIS, L., GREENGARD, P. and BRIVANLOU,
A.H. (2004). Maintenance of pluripotency in human and mouse embryonic stem cells through activation of Wnt signaling by a pharmacological GSK-3-specific inhibitor. Nat Med 10: 55-63.

SCHICKL, H., BRAUN, M. and DABROCK, P. (2017). Ways Out of the Patenting Prohibition? Human Parthenogenetic and Induced Pluripotent Stem Cells. Bioethics 31: 409-417.

SCHMALTZ-PANNEAU B, JOUNEAU L, OSTEIL P, TAPPONNIER Y, AFANASSIEFF M, MOROLDO M, JOUNEAU A, DANIEL N, ARCHILLAC, SAVATIER P, DURANTHON V (2014). Contrasting transcriptome landscapes of rabbit pluripotent stem cells in vitro and in vivo. Anim Reprod Sci 149: 67-79.

SESHAGIRI, P.B., MC KENZIE, D., BAVISTER, B.D., WILLIAMSON, J.L. and AIKEN J.M. (1992). Golden Hamster Embryonic Genome Activation Occurs at the TwoCell Stage: Correlation With Major Developmental Changes. Mol Reprod Dev32.

SILVA, S.S., ROWNTREE, R.K., MEKHOUBAD, S. and LEE, J.T. (2008). X-chromosome inactivation and epigenetic fluidity in human embryonic stem cells. Proc Natl Acad Sci USA 105: 4820-4825.

SIMMET, K., ZAKHARTCHENKO, V., PHILIPPOU-MASSIER, J., BLUM, H., KLYMIUK, N. and WOLF, E. (2018). OCT4/POU5F1 is required for NANOG expression in bovine blastocysts. Proc Natl Acad Sci USA. 115: 2770-2775

SINGH AM, HAMAZAKI T, HANKOWSKI KE, TERADA N (2007). A heterogeneous expression pattern for Nanog in embryonic stem cells. Stem Cells 25: 2534-2542.

SONG J, ZHONG J, GUO X, CHEN Y, ZOU Q, HUANG J, LI X, ZHANG Q, JIANG Z, TANG C, YANG H, LIU T, LI P, PEI D, LAI L (2013). Generation of RAG 1- and 2-deficient rabbits by embryo microinjection of TALENs. Cell Res 23: 1059-1062.

SOZEN, B., CAN, A. and DEMIR, N. (2014). Cell fate regulation during preimplantation development: a view of adhesion-linked molecular interactions. DevBio/395:73-83.

STOUT, T.A., MEADOWS, S. and ALLEN, W.R. (2005). Stage-specific formation of the equine blastocyst capsule is instrumental to hatching and to embryonic survival in vivo. Anim Reprod Sci 87: 269-281.

STRAIN, L., WARNER, J.P., JOHNSTON, T. and BONTHRON, D.T. (1995). A human parthenogenetic chimaera. Nat Genet 11: 164.

STRUMPF D, MAO C-A, YAMANAKA Y, RALSTON A, CHAWENGSAKSOPHAK K, BECK F, ROSSANT J (2005). Cdx2 is required for correct cell fate specification and differentiation of trophectoderm in the mouse blastocyst. Development 132 : 2093-2102.

SUI T, LAU YS, LIU D, LIU T, XU L, GAO Y, LAI L, LI Z, HAN R (2018). A novel rabbit model of Duchenne muscular dystrophy generated by CRISPR/Cas9. Dis Model Mech 11(6). pii: dmm032201. doi: 10.1242/dmm.032201.

SUI T, XU L, LAU YS, LIU D, LIU T, GAO Y, LAI L, HAN R, LI Z (2018). Development of muscular dystrophy in a CRISPR-engineered mutant rabbit model with framedisrupting ANO5 mutations. Cell Death Dis 9: 609.

SURANI, M.A., BARTON, S.C. and KAUFMAN, M.H. (1977). Development to term of chimaeras between diploid parthenogenetic and fertilised embryos. Nature 270: 601-603.

TABANSKY, I., LENARCIC, A., DRAFT, R.W., LOULIER, K., KESKIN, D.B., ROSAINS J., RIVERA-FELICIANO, J., LICHTMAN, J.W., LIVET, J., STERN, J.N. etal., (2013). Developmental bias in cleavage-stage mouse blastomeres. Curr Biol 23: 21-31.

TAN T, TANG X, ZHANG J, NIU Y, CHEN H, LI B, WEI Q, JI W (2011). Generation of trophoblast stem cells from rabbit embryonic stem cells with BMP4. PloS One 6: e17124.

TÁNCOS Z, BOCK I, NEMES C, KOBOLÁK J, DINNYÉS A (2015). Cloning and characterization of rabbit POU5F1, SOX2, KLF4, C-MYC and NANOG pluripotencyassociated genes. Gene 566: 148-157.

TÁNCOS Z, NEMES C, VARGA E, BOCK I, RUNGARUNLERT S, THARASANIT T, TECHAKUMPHU M, KOBOLÁK J, DINNYÉS A (2017). Establishment of a rabbit induced pluripotent stem cell (RbiPSC) line using lentiviral delivery of human pluripotency factors. Stem Cell Res 21: 16-18.

TAPPONNIER Y, AFANASSIEFF M, AKSOY I, AUBRY M, MOULIN A, MEDJANI L, BOUCHEREAU W, MAYĖRE C, OSTEIL P, NURSE-FRANCIS J, et al., (2017). Reprogramming of rabbit induced pluripotent stem cells toward epiblast and chimeric competency using Krüppel-like factors. Stem Cell Res 24: 106-117.

TARKOWSKI, A.K. (1959). Experiments on the development of isolated blastomers of mouse eggs. Nature 184: 1286-1287.

TARKOWSKI, A.K. (1971). Recent studies on parthenogenesis in the mouse. $J$ Reprod Fertil Suppl 14: 31-39. 
TARKOWSKI, A.K., WITKOWSKA, A. and NOWICKA, J. (1970). Experimental partheonogenesis in the mouse. Nature 226: 162-165.

TESAR, P.J., CHENOWETH, J.G., BROOK, F.A., DAVIES, T.J., EVANS, E.P., MACK, D.L., GARDNER, R.L. and MCKAY, R.D. (2007). New cell lines from mouse epiblast share defining features with human embryonic stem cells. Nature 448: 196-199.

THIEME R, RAMIN N, FISCHER S, PÜSCHEL B, FISCHER B, SANTOS AN (2012). Gastrulation in rabbit blastocysts depends on insulin and insulin-like-growth-factor 1. Mol Cell Endocrinol 348: 112-119.

THOMSON, J.A. (1998). Embryonic Stem Cell Lines Derived from Human Blastocysts. Science 282: 1145-1147.

THOMSON, J.A., KALISHMAN, J., GOLOS, T.G., DURNING, M., HARRIS, C.P., BECKER, R.A. and HEARN, J.P. (1995). Isolation of a primate embryonic stem cell line. Proc Natl Acad Sci USA 92: 7844-7848.

TIAN, X.C., KUBOTA, C., ENRIGHT, B. and YANG, X. (2003). Cloning animals by somatic cell nuclear transfer--biological factors. Reprod Biol Endocrinol 1: 98.

TILGHMAN, S.M. (1999). The Sins of the Fathers and Mothers. Cell 96: 185-193.

TSUNODA Y, SOMA T, SUGIE T (1982). Effect of post-ovulatory age of recipient on survival of frozen-thawed rabbit morulae. J Reprod Fertil 65: 483-487.

TSUNODA, Y. and MCLAREN, A. (1983). Effect of various procedures on the viability of mouse embryos containing half the normal number of blastomeres. $J$ Reprod Fertil 69: 315-322.

VAN AMERONGEN, R. and NUSSE, R. (2009). Towards an integrated view of Wnt signaling in development. Development 136: 3205-3214.

VAN LEEUWEN, J., BERG, D.K. and PFEFFER, P.L. (2015). Morphological and Gene Expression Changes in Cattle Embryos from Hatched Blastocyst to Early Gastrulation Stages after Transfer of In vitro Produced Embryos. PLoS One 10: e0129787.

VAN LEEUWEN, J., BERG, D.K., SMITH, C.S., WELLS, D.N. and PFEFFER, P.L. (2014). Specific epiblast loss and hypoblast impairment in cattle embryos sensitized to survival signalling by ubiquitous overexpression of the proapoptotic gene BAD. PLoS One 9: e96843.

VAN SOOM, A., YSEBAERT, M.T. and DE KRUIF, A. (1997). Relationship Between Timing of Development, Morula Morphology, and Cell Allocation to Inner Cell Mass and Trophectoderm in In Vitro-Produced Bovine Embryos. Mol Reprod Dev 47: 47-56.

VANNESTE, E., VOET, T., MELOTTE, C., DEBROCK, S., SERMON, K., STAESSEN, C., LIEBAERS, I., FRYNS, J.P., D'HOOGHE, T. and VERMEESCH, J.R. (2009). What next for preimplantation genetic screening? High mitotic chromosome instability rate provides the biological basis for the low success rate. Hum Reprod 24: 2679-2682.

VASSILIEV, I., VASSILIEVA, S., BEEBE, L.F.S., HARRISON, S.J., MCILFATRICK, S.M. and NOTTLE, M.B. (2010). In vitro and In vivo Characterization of Putative Porcine Embryonic Stem Cells. Cell Reprogram 12: 223-230.

VASSILIEV, I., VASSILIEVA, S., TRUONG, K.P., BEEBE, L.F.S., MCILFATRICK, S.M., HARRISON, S.J. and NOTTLE, M.B. (2011). Isolation and In vitro Characterization of Putative Porcine Embryonic Stem Cells from Cloned Embryos Treated with Trichostatin A. Cell Reprogram 13: 205-213.

VRANA, K.E., HIPP, J.D., GOSS, A.M., MCCOOL, B.A., RIDDLE, D.R., WALKER, S.J., WETTSTEIN, P.J., STUDER, L.P., TABAR, V., CUNNIFF, K. et al., (2003). Nonhuman primate parthenogenetic stem cells. Proc Natl Acad Sci USA. 100: 11911-11916.

WANG S, TANG X, NIU Y, CHEN H, LI B, LI T, ZHANG X, HU Z, ZHOU Q, JI W (2007). Generation and characterization of rabbit embryonic stem cells. Stem Cells 25: 481-489.

WANG, D., LIU, Z., YAO, H., HAO, Y., ZHOU, L., DU, J., ZHU, Y., XU, Y., WANG, G., SONG, Y. et al., (2017). Disruption of NNAT, NAP1L5 and MKRN3 DNA methylation and transcription in rabbit parthenogenetic fetuses. Gene 626: 158-162.

WATERS, W.R., PALMER, M.V., THACKER, T.C., DAVIS, W.C., SREEVATSAN, S.,
COUSSENS, P., MEADE, K.G., HOPE, J.C., ESTES, D.M. (2011). Tuberculosis immunity: opportunities from studies with cattle. Clin Dev Immunol 2011: 768542

WILCOXJT, SEMPLEE, GARTLEYC, BRISSONBA, PERRAULT SD, VILLAGÓMEZ DAF, TAYADE C, BECKER S, LANZA R, BETTS DH (2009). Characterization of Canine Embryonic Stem Cell Lines Derived From Different Niche Microenvironments. Stem Cells Dev 18: 1167-1178.

WILLADSEN, S.M. (1980). The viability of early cleavage stages containing half the normal number of blastomeres in the sheep. $J$ Reprod Fertil 59: 357-362.

WILLADSEN, S.M. (1981). The development capacity of blastomeres from 4- and 8-cell sheep embryos. J Embryol Exp Morphol. 65:165-72.ZHAO, H., JIN, Y. (2017) Signaling networks in the control of pluripotency. Curr Opin GenetDev. 46:141-148.

WOLF, X.A., RASMUSSEN, M.A., SCHAUSER, K., JENSEN, A.T., SCHMIDT, M. and HYTTEL, P. (2011). OCT4 expression in outgrowth colonies derived from porcine inner cell masses and epiblasts. Reprod Domest Anim 46: 385-392.

XU, R.H., SAMPSELL-BARRON, T.L., GU, F., ROOT, S., PECK, R.M., PAN, G., YU, J., ANTOSIEWICZ-BOURGET, J., TIAN, S., STEWART, R. et al., (2008). NANOG is a direct target of TGFbeta/activin-mediated SMAD signaling in human ESCs. Cell Stem Cell 3: 196-206.

XU Y, WANG Y, SONG Y, DENG J, CHEN M, OUYANG H, LAI L, LI Z (2018). Generation and Phenotype Identification of PAX4 Gene Knockout Rabbit by CRISPR/ Cas9 System. G3 Bethesda Md 8: 2833-2840.

YAMANAKA Y, LANNER F, ROSSANT J (2010). FGF signal-dependent segregation of primitive endoderm and epiblast in the mouse blastocyst. Development 137 715-724.

YAN Q, ZHANG Q, YANG H, ZOU Q, TANG C, FAN N, LAI L (2014). Generation of multi-gene knockout rabbits using the Cas9/gRNAsystem. Cell Regen (Lond)3:12

YANG D, SONG J, ZHANG J, XU J, ZHU T, WANG Z, LAI L, CHEN YE (2016). Identification and characterization of rabbit ROSA26 for gene knock-in and stable reporter gene expression. Sci Rep 6: 25161.

YANG D, XU J, ZHU T, FAN J, LAI L, ZHANG J, CHEN YE (2014). Effective gene targeting in rabbits using RNA-guided Cas9 nucleases. J Mol Cell Biol 6: 97-99.

YANG, J.-R., HSU, C.-W., LIAO, S.-C., LIN, Y.-T., CHEN, L.-R. and YUAN, K. (2013a) Transplantation of embryonic stem cells improves the regeneration of periodontal furcation defects in a porcine model. J Clin Periodontol 40: 364-371.

YANG, J.-R., LIAO, C.-H., PANG, C.-Y., HUANG, L.L.-H., CHEN, Y.-L., SHIUE, Y.-L. and CHEN, L.-R. (2013b). Transplantation of porcine embryonic stem cells and their derived neuronal progenitors in a spinal cord injury rat model. Cytotherapy 15: 201-208

YAPURA, J., MAPLETOFT, R.J., PIERSON, R., SINGH, J., NAILE, J., GIESY, J.P., ADAMS, G.P., (2011). A bovine model for examining the effects of an aromatase inhibitor on ovarian function in women. Fertil Steril 96: 434-438 e433.

YIN M, FANG Z, JIANG W, XING F, JIANG M, KONG P, LI Y, ZHOU X, TANG L, LI S, CHEN X (2013). The Oct4 promoter-EGFP transgenic rabbit: a new mode for monitoring the pluripotency of rabbit stem cells. Int J Dev Biol 57: 845-852.

YING, Q.L., WRAY, J., NICHOLS, J., BATLLE-MORERA, L., DOBLE, B., WOODGETT, J., COHEN, P. and SMITH, A. (2008). The ground state of embryonic stem cell self-renewal. Nature 453: 519-523.

ZAKHARTCHENKO V., FLISIKOWSKA T., LI S., RICHTER T., WIELAND H., DURKOVIC M., ROTTMANN O., KESSLER B., GUNGOR T., BREM G., KIND A., WOLF E., SCHNIEKE A. (2011). Cell-mediated transgenesis in rabbits: chimeric and nuclear transfer animals. Biol Reprod 84: 229-237.

ZERNICKA-GOETZ, M. (1994). Activation of embryonic genes during preimplantation rat development. Mol Reprod Dev 38: 30-38.

ZHANG, Y., YANG, Z. and WU, J. (2007). Signaling pathways and preimplantation development of mammalian embryos. FEBS J 274: 4349-4359.

ZIOMEK CA, CHATOT CL, MANES C (1990). Polarization of blastomeres in the cleaving rabbit embryo. J Exp Zool 256: 84-91. 


\section{Further Related Reading, published previously in the Int. J. Dev. Biol.}

The Oct4 promoter-EGFP transgenic rabbit: a new model for monitoring the pluripotency of rabbit stem cells Mingru Yin, Zhenfu Fang, Weihua Jiang, Fengying Xing, Manxi Jiang, Pengcheng Kong, Yao Li, Xiaomei Zhou, Lan Tang, Shangang Li and Xuejin Chen.

Int. J. Dev. Biol. (2013) 57: 845-852

Metabolism throughout follicle and oocyte development in mammals

Esther Collado-Fernandez, Helen M. Picton and Rémi Dumollard

Int. J. Dev. Biol. (2012) 56: 799-808

Porcine induced pluripotent stem cells analogous to naïve and primed embryonic stem cells of the mouse Bhanu Prakash V.L. Telugu, Toshihiko Ezashi and R. Michael Roberts

Int. J. Dev. Biol. (2010) 54: 1703-1711

https://doi.org/10.1387/ijdb.103200bt

Porcine induced pluripotent stem cells analogous to naïve and primed embryonic stem cells of the mouse Bhanu Prakash V.L. Telugu, Toshihiko Ezashi and R. Michael Roberts

Int. J. Dev. Biol. (2010) 54: 1703-1711

Animal reproduction biotechnology in Poland

Zdzislaw Smorag, Lucyna Katska-Ksiazkiewicz, Maria Skrzyszowska, Jacek Jura, Barbara Gajda and Michal Bochenek

Int. J. Dev. Biol. (2008) 52: 151-155

https://doi.org/10.1387/ijdb.072325zs

Experimental embryology of mammals at the Jastrzebiec Institute of Genetics and Animal Breeding

Jolanta Karasiewicz and Jacek Andrzej Modlinski

Int. J. Dev. Biol. (2008) 52: 157-161

https://doi.org/10.1387/ijdb.072316jk

Histone methylation defines epigenetic asymmetry in the mouse zygote Katharine L Arney, Siqin Bao, Andrew J Bannister, Tony Kouzarides and M Azim Surani Int. J. Dev. Biol. (2002) 46: 317-320

http://www.intjdevbiol.com/web/paper/12068953

Germ cells, gonads and sex reversal in marsupials

$M$ B Renfree and G Shaw

Int. J. Dev. Biol. (2001) 45: 557-567

http://www.intjdevbiol.com/web/paper/11417899
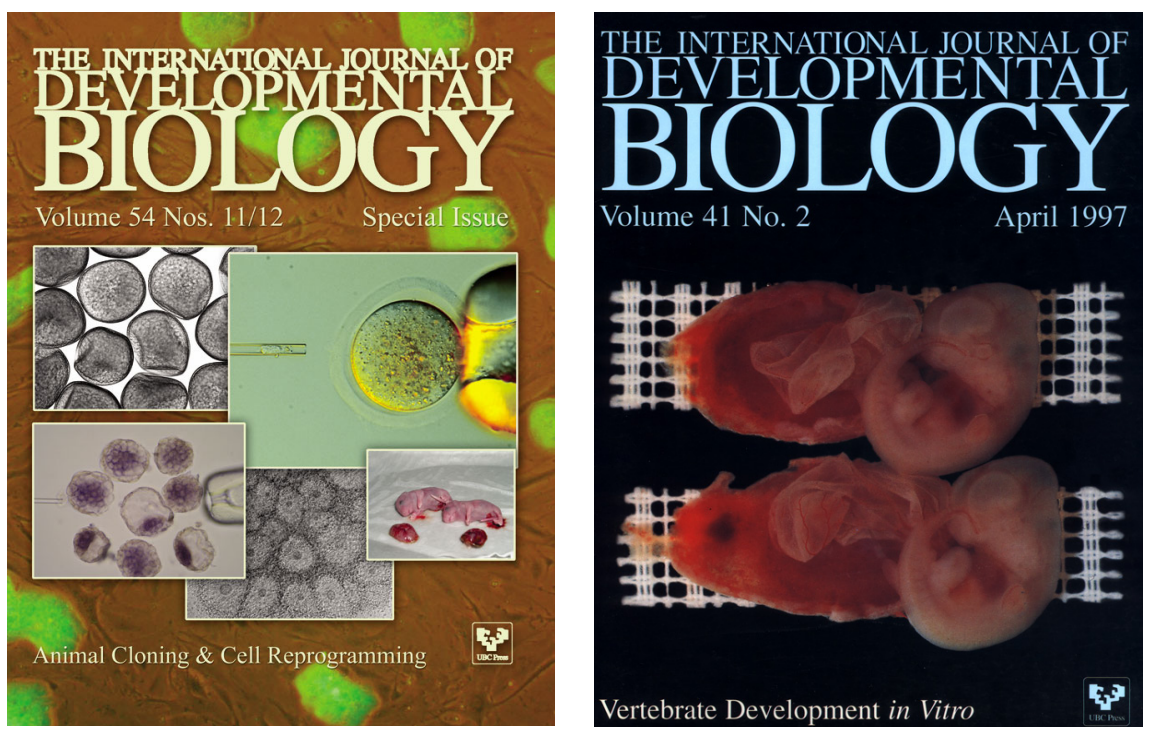
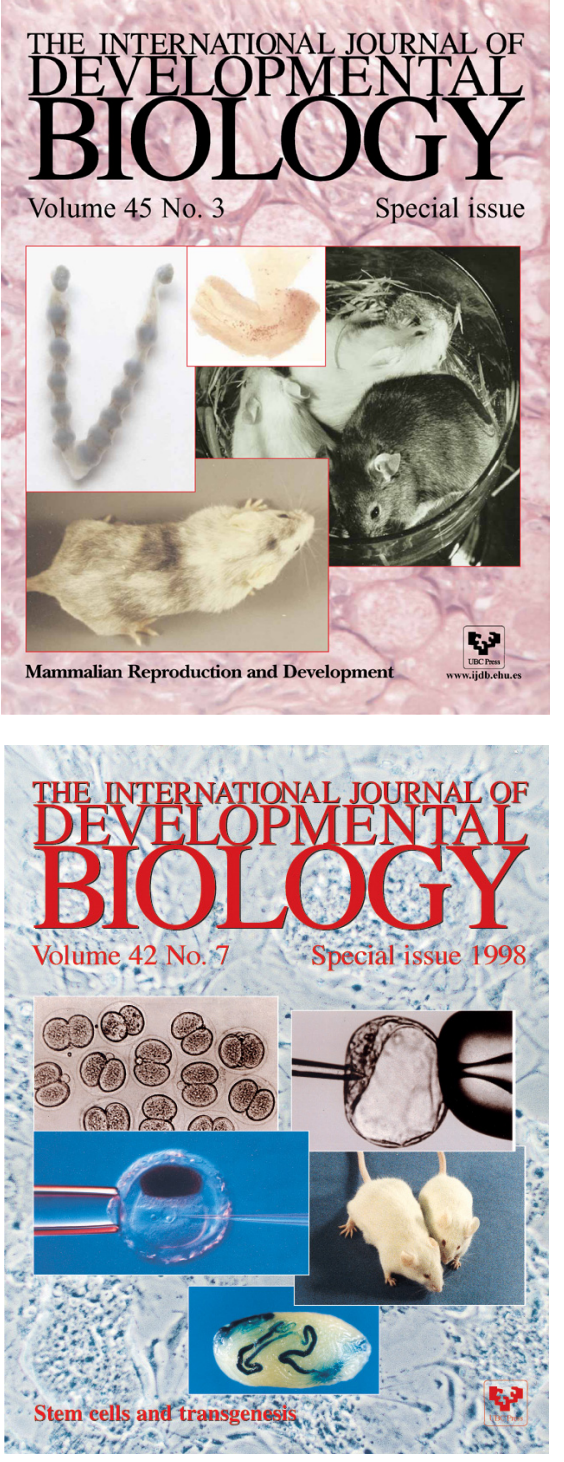